\title{
AIRLIFT MINI-BUBBLER TESTING IN THE SLURRY FED MELT RATE FURANCE (U)
}

D. C. Witt

T. M. Jones

D F. Bickford

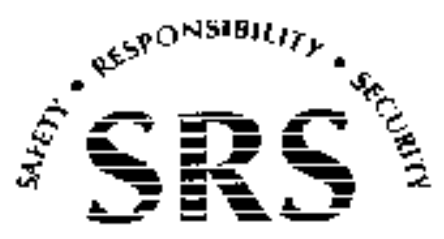

PREPARED FOR THE U.S. DEPARTMENT OF ENERGY UNDER CONTRACT NO. DE-AC09-96SR18500 
This document was prepared in conjunction with work accomplished under Contract No. DE-AC09-96SR18500 with the U. S. Department of Energy.

\section{DISCLAIMER}

This report was prepared as an account of work sponsored by an agency of the United States Government. Neither the United States Government nor any agency thereof, nor any of their employees, makes any warranty, express or implied, or assumes any legal liability or responsibility for the accuracy, completeness, or usefulness of any information, apparatus, product or process disclosed, or represents that its use would not infringe privately owned rights. Reference herein to any specific commercial product, process or service by trade name, trademark, manufacturer, or otherwise does not necessarily constitute or imply its endorsement, recommendation, or favoring by the United States Government or any agency thereof. The views and opinions of authors expressed herein do not necessarily state or reflect those of the United States Government or any agency thereof.

This report has been reproduced directly from the best available copy.

Available for sale to the public, in paper, from: U.S. Department of Commerce, National Technical Information Service, 5285 Port Royal Road, Springfield, VA 22161, phone: (800) 553-6847, fax: (703) 605-6900

email: orders@ntis.fedworld.gov

online ordering: http://www.ntis.gov/help/index.asp

Available electronically at http://www.osti.gov/bridge

Available for a processing fee to U.S. Department of Energy and its contractors, in paper, from: U.S. Department of Energy, Office of Scientific and Technical Information, P.O. Box 62, Oak Ridge, TN 37831-0062,

phone: (865)576-8401,

fax: (865)576-5728

email: $\underline{\text { reports@ adonis.osti.gov }}$ 
Keywords:

Retention: Permanent

\section{AIRLIFT MINI-BUBBLER TESTING IN THE SLURRY FED MELT RATE FURANCE (U)}

D. C. Witt

T. M. Jones

D. F. Bickford

Publication Date: November 4, 2002

Westinghouse Savannah River Company

Savannah River Site

Aiken, SC 29808

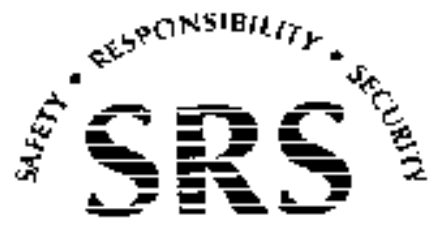

SAVAHNAH RIVER SI L L

PREPARED FOR THE U.S. DEPARTMENT OF ENERGY UNDER CONTRACT NO. DE-AC09-96SR18500 


\section{TABLE OF CONTENTS}

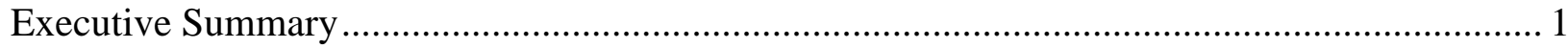

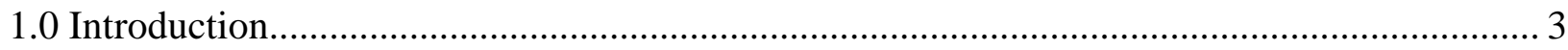

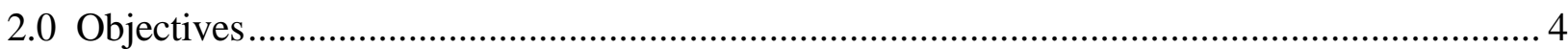

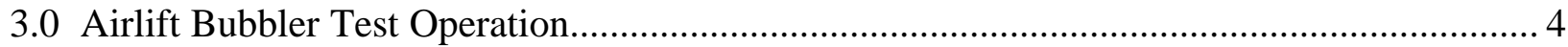

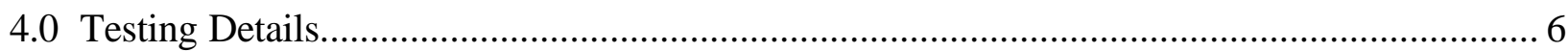

4.1 ACTL Bubbler Tests - Frit 320/Sludge Batch 2 (SB2) Feed .......................................... 6

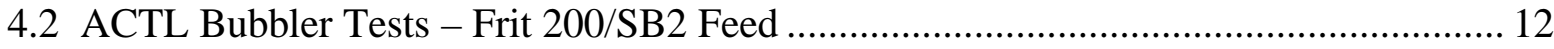

4.3 CETL Bubbler Tests - Frit 320/SB2 Feed.................................................................. 14

4.3.1 High Batch Solids Runs - CETL SMRF ........................................................... 17

4.3.2 CETL Lower Plenum Temperature Runs ........................................................... 18

4.3.3 CETL Standard Batch Solids Runs .................................................................... 19

4.3.4 Modified Bubbler Location - CETL SMRF.................................................... 21

5.0 Conclusions - Mini-Bubbler Performance with Frit 320 and Frit 200................................... 22

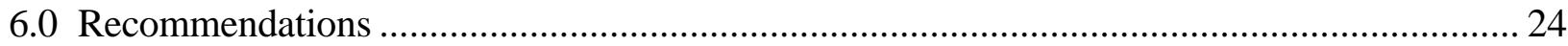

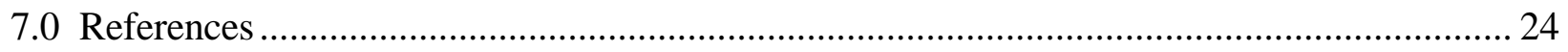




\section{LIST OF FIGURES}

Figure 1. Comparison of Conventional Bubbler and Airlift Bubbler ........................................ 3

Figure 2. ACTL Slurry Fed Melt Rate Furnace ........................................................... 5

Figure 3. CETL Slurry Fed Melt Rate Furance.................................................................... 5

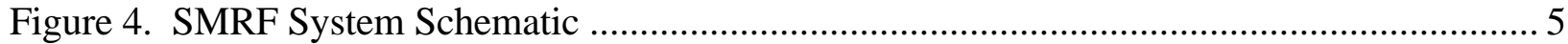

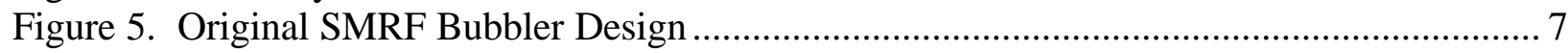

Figure 6. Bubbler Location - SMRF Plan View ................................................................... 7

Figure 7. Frit 320/SB2 Run With Bubbler - 7/22/2002 ….................................................... 8

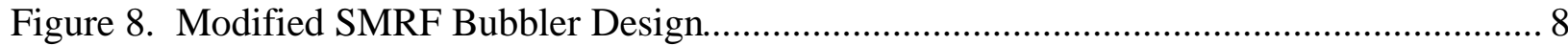

Figure 9. Frit 320 / SB2 Run Baseline Run - 7/30/02 ................................................... 10

Figure 10. Frit 320 / SB2 Run With Bubbler - 7/31/02 ................................................ 11

Figure 11. Cold Cap and Vent Hole -Frit 320 / SB2 Run - 7/31/02 _................................... 11

Figure 12. Frit 200 / SB2 Baseline Run - 8/7/02 .............................................................. 13

Figure 13. Frit 200 / SB2 Bubbler Run - 8/8/02 .............................................................. 14

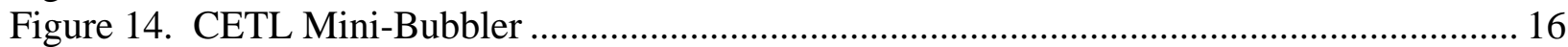

Figure 15. CETL Frit 320 / SB2 Baseline (High Wt\% Solids) Run - 8/30/02 .......................... 17

Figure 16. CETL Frit 320 / SB2 Bubbler (High Wt\% Solids) Run - 9/3/02........................... 18

Figure 17. CETL Frit 320 / SB2 Low Plenum Temp Run - 9/4/02 ...................................... 19

Figure 18. CETL Frit 320 / SB2 Bubbler Run - 9/5/02 …..................................................... 20

Figure 19. CETL Frit 320 / SB2 Baseline Run - 9/27/02 ..................................................... 21

Figure 20. CETL Frit 320 / SB2 Modified Bubbler Run - 9/30/02 ........................................ 22

\section{LIST OF TABLES}

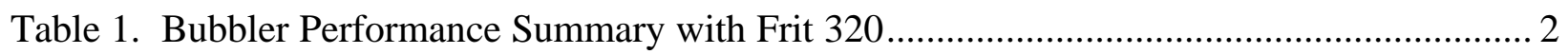

Table 2 ACTL SMRF Melt Rate Tests with SB2 …....................................................... 6

Table 3. Black Frit Composition........................................................................................... 12

Table 4. SMRF SB2 Feed Compositions Before Frit Addition........................................ 15

Table 5. CETL SMRF Melt Rate Tests.................................................................................. 16

Table 6. Bubbler Performance Summary with Frit 320 ...................................................... 23

Table 7. SMRF Power Summary with Frit 320 ..................................................................... 23 


\section{Executive Summary}

Development of the airlift bubbler was initiated as part of a FY01 DOE Tank Focus Area program to assess possible means of increasing melt rate in the Defense Waste Processing Facility (DWPF) Melter. Airlift bubblers are considered a means of increasing glass circulation within a vessel, thus transferring additional energy from within the melt pool to the pool surface (cold cap) to better utilize electrode power. Prior work with a prototype bubbler revealed several engineering concerns related to the operation of the bubbler that warranted further investigation. These areas of investigation include the lifespan and possible failure modes of the bubbler; airlift bubbler interaction with the slurry feed, cold cap and foamy interface layer; and the impact on pressure control, off-gas surges, and offgas entrainment.

In an effort to address each of these concerns and structure the airlift bubbler development effort, a bubbler development program was developed. The bubbler development program employs the use of small melters, while minimizing scale up risks to DWPF. The resulting path forward consists of: 1) full scale testing with glycerin to characterize bubbler performance; 2) minibubbler tests in a Slurry Fed Melt Rate Furnace (SMRF) to investigate cold cap / foam behavior and melt rate; 3) wear testing (corrosion/erosion) of a full scale prototype Inconel 690 bubbler in the Pour Spout Test Stand at Clemson Environmental Technologies Laboratory (CETL) for 1-2 months; and 4) FIDAP model evaluation to assess the impact of a bubbler on DWPF Melter performance. This report covers the second program element, the evaluation of a mini-bubbler in a SMRF to assess melting behavior and melt rate enhancement. The results of other program elements are discussed and documented elsewhere.

Results from the mini-bubbler tests for Frit 320/Sludge Batch 2 (SB2) are summarized in Table 1. For the ACTL test the bubbler discharge was positioned about $1 / 4$ inch below the glass pool/cold cap interface while for the CETL tests shown in Table 1, the bubbler discharge was positioned at the glass pool/cold cap interface. With Frit 320 the bubbler discharge vent through the cold cap was maintained during each of the test periods. On occasion the feed covered the bubbler discharge vent but within a short time period (1 to 2 minutes) the vent re-appeared. The bubbler air was readily vented to the melter vapor space and no adverse effects on cold cap stability, foam persistence or entrainment were observed. An $8.8 \%$ melt rate increase was observed when the bubbler was used in the ACTL SMRF. At comparable operating conditions the longer bubbler used in the CETL SMRF yielded a $12.0 \%$ melt rate increase, supporting the prediction of increased glass pumping with the longer draft tube. A much larger increase was obtained when the higher ( $52 \mathrm{wt} \%$ ) solids feed was used with the CETL SMRF bubbler presumably because of improved distribution of the feed over the melt pool surface (i.e. increased cold cap coverage).

With Frit 200 however, a cold cap vent could not be maintained and a thick crusty cold cap formed that grew with processing time. The cold cap trapped the bubbler air, which pressurized the melt pool and significantly increased the pour rate. As a result, no reliable melt rate determination could be made when the small bubbler was used with Frit 200. Raising the bubbler elevation, using a longer draft tube (CETL SMRF), or discharging in or on the cold cap may produce more favorable results with Frit 200 and should be evaluated. The bubbler proposed for 
DWPF would have greatly increased flow, and is therefore more likely to locally burn through the cold cap, and maintain an open vent path.

Table 1. Bubbler Performance Summary with Frit 320

\begin{tabular}{|c|c|c|c|c|c|}
\hline Operating Condition & $\begin{array}{c}\text { SMRF } \\
\text { Location }\end{array}$ & $\begin{array}{c}\text { Feed Solids } \\
\mathrm{wt} \%\end{array}$ & $\begin{array}{c}\text { Bubbler } \\
\text { Flow Rate } \\
\text { scc/min }\end{array}$ & $\begin{array}{c}\text { Plenum } \\
\text { Temperature } \\
{ }^{\circ} \mathrm{C}\end{array}$ & $\begin{array}{c}\text { Melt Rate } \\
\text { Increase } \\
\%\end{array}$ \\
\hline Std Cond $40 \mathrm{wt} \%, 750^{\circ} \mathrm{C}$ & ACTL & 40 & 15 & 750 & 8.8 \\
\hline Low Plenum Temp, $650^{\circ} \mathrm{C}$ & CETL & 41 & 5 & 650 & 14.3 \\
\hline High Feed Solids $52 \mathrm{wt} \%$ & CETL & 52 & 5 & 750 & 39.1 \\
\hline Std Cond $40 \mathrm{wt} \%, 750^{\circ} \mathrm{C}$ & CETL & 41 & 5 & 750 & 12.0 \\
\hline
\end{tabular}

Inspection of the power data shows that the impact of the bubbler was to increase the usable melt pool power and decrease the demand for vapor space power. The additional energy from the melt pool was effective in increasing melt rate. It appears, however, based on visual observation, that the foam layer in the cold cap is still a dominant factor limiting melt rate. The bubbler and Frit 320 are steps in the right direction, but eliminating the foam layer would appear to offer significant improvements in melt rate and melting behavior.

Feed distribution of the $52 \mathrm{wt} \%$ solids feed over the melt pool surface was definitely a problem. As the feed was delivered onto the melt pool it mounded directly beneath the feed tube. Subsequent feed additions tended to only further increase the mass of the fed solids in the mound. The mounding reduced the percent cold cap coverage and the area available for heat transfer reducing melt rate. Increasing the feed solids from $41 \mathrm{wt} \%$ to $52 \mathrm{wt} \%$ decreased melt rate by $23.4 \%$.

A $100{ }^{\circ} \mathrm{C}$ drop in plenum temperature from $750{ }^{\circ} \mathrm{C}$ to $650{ }^{\circ} \mathrm{C}$ had a pronounced impact on melt rate decreasing it nearly $40 \%$. This was the result of decreased radiative transfer from the plenum heaters. Adding a bubbler to the $650{ }^{\circ} \mathrm{C}$ plenum test improved melt rate to $14.3 \%$, but it was still $29 \%$ lower than the rate obtained at $750{ }^{\circ} \mathrm{C}$. At the lower plenum temperature it was also much easier to get into an over feeding situation (feed rate exceeds melt rate). These observations may well have an impact on the DWPF melter operation. It may be advantageous for DWPF melter operation to control the slurry feed rate based on cold cap visual observation and melter pressure performance, rather than only on vapor space temperature as is the current practice. 


\subsection{Introduction}

Development of the airlift bubbler was initiated as part of a FY01 DOE Tank Focus Area program to assess possible means of increasing DWPF Melter melt rate. Analysis of the DWPF Melter performance since 1997 has shown that electrode power has continuously decreased presumably due to a foamy, thermal resistance layer in the cold cap. ${ }^{1}$ Electrode power is currently limited by upper temperature of the glass to protect melter parts. Consequently, melt rate has continued to drop. Bubblers were considered as a means of increasing glass circulation and opening a vent in the cold cap to allow increased use of available electrode power. Radiant heat from this vent would supplement the dome heater power and hence, increase the melter capacity. An innovative bubbler system, using the airlift principle, was designed for the DWPF melter. The airlift bubbler has significant advantages over conventional bubblers in that hot glass is pumped in a controlled and adjustable manner from lower elevations in the melter to a surface layer adjacent to the cold cap to increase gross melter circulation and improve heat transfer. Conventional bubblers basically only provide local agitation. In addition, the airlift bubbler uses minimal air, which should minimize wear from erosion and corrosion and reduce off gas entrainment. A comparison of the two bubblers is depicted in Figure 1.

\section{Figure 1. Comparison of Conventional Bubbler and Airlift Bubbler}
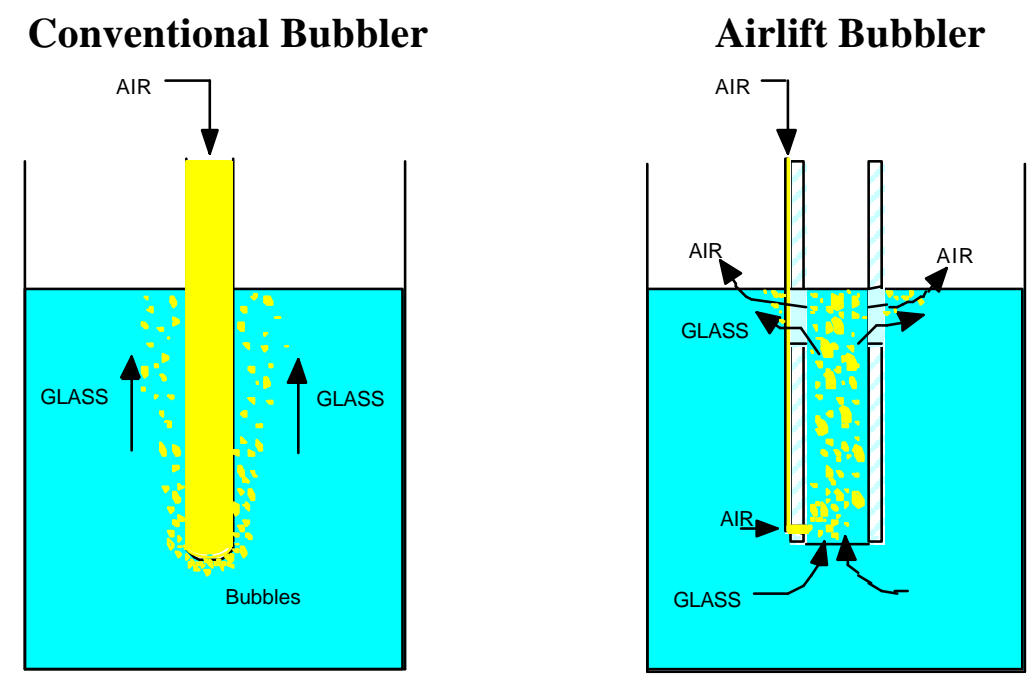

A comprehensive description of the early airlift bubbler work covering the initial glycerin testing and Stirred Melter tests is given in Reference 2. As a result of this work a number of potential engineering issues related to the operation of the bubbler were identified and are listed below:

- Airlift bubbler interaction with slurry feed, cold cap and foamy interface layer

- Best elevation for bubbler glass discharge

- Bubbler air venting

- Persistence of foam or additional foam formation

- Impact on offgas, pressure control, and surges

- Optimum bubbler gas flow 
- Bubbler life and failure mode of detailed prototypic design

- Monitoring and control of bubbler

- Thermocouples \& borescope to monitor operation

- Solids carryover into offgas system.

A bubbler development program was defined to address each of these potential engineering issues using small melters with minimal scale up risks to DWPF. The resulting path forward, which had the goal of supplying an engineering drawing of the bubbler to the DWPF, consisted of the following four elements:

- Full scale testing with glycerin to characterize bubbler performance ${ }^{3}$

- Mini-bubbler tests in a Slurry Fed Melt Rate Furnace (SMRF) to investigate cold cap /foam behavior and melt rate,

- Wear testing (corrosion/erosion) of a full scale Inconel 690 bubbler in the Pour Spout Test Stand at CETL for 1-2 months and

- FIDAP computer model evaluation to assess the impact of a bubbler on DWPF Melter performance.

This report will cover the second program element, the evaluation of two lengths of minibubblers in SMRFs to assess melting behavior and melt rate enhancement.

\subsection{Objectives}

The objectives of the mini airlift bubbler testing are to evaluate the impact of the bubbler on melt rate, melting behavior and cold cap structure, foam formation and stability, bubbler air venting, off gas behavior, and electrode/plenum power use. In addition, the effects of frit and plenum temperature on bubbler performance were evaluated.

\subsection{Airlift Bubbler Test Operation}

Mini-bubbler testing was conducted in the SMRF installed at the Aiken County Technology Laboratory (ACTL) and at the Clemson Environmental Technologies Laboratory (CETL). These furnaces were utilized to compare the melting behavior of different DWPF slurry feed formulations both with and without a mini-bubbler. The SMRFs were designed to mimic the heat transfer characteristics of a large-scale joule-heated melter. This was done by providing heating in one dimension (vertically) through the bottom of an 8 inch diameter Inconel 690 crucible with insulation around the sides of the crucible in the melt pool area to minimize radial heat transfer to or from the melt pool and heat exchange with the plenum. Sketches of the ACTL and CETL furnaces are shown in Figures 2 and 3, respectively. A schematic depicting the SMRF system at both ACTL and CETL is shown in Figure 4. 
Figure 2. ACTL Slurry Fed Melt Rate Furnace

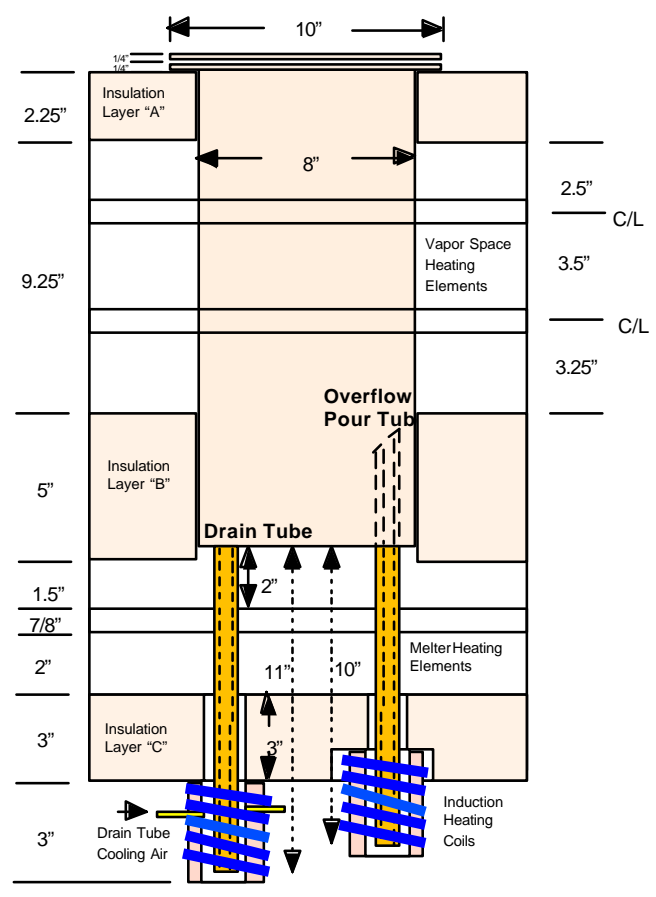

Figure 3. CETL Slurry Fed Melt Rate Furnace

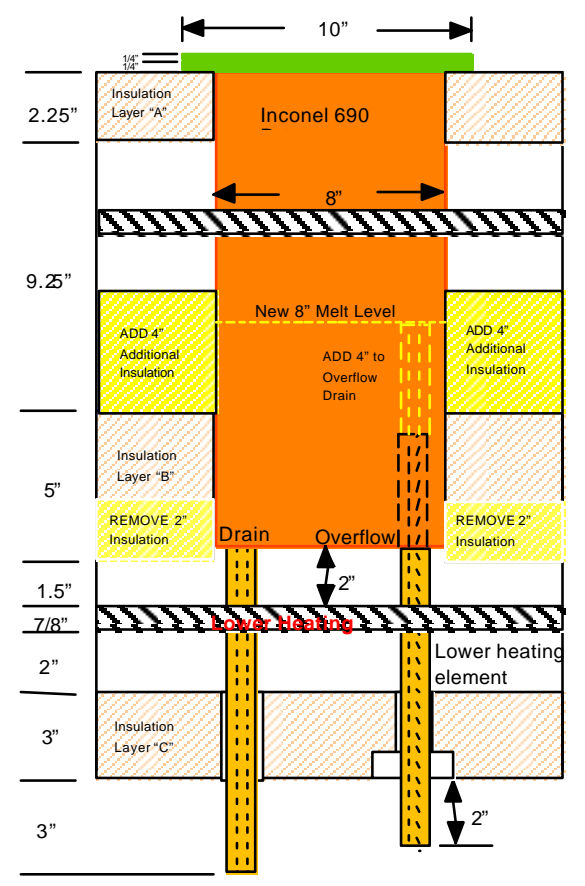

Figure 4. SMRF System Schematic

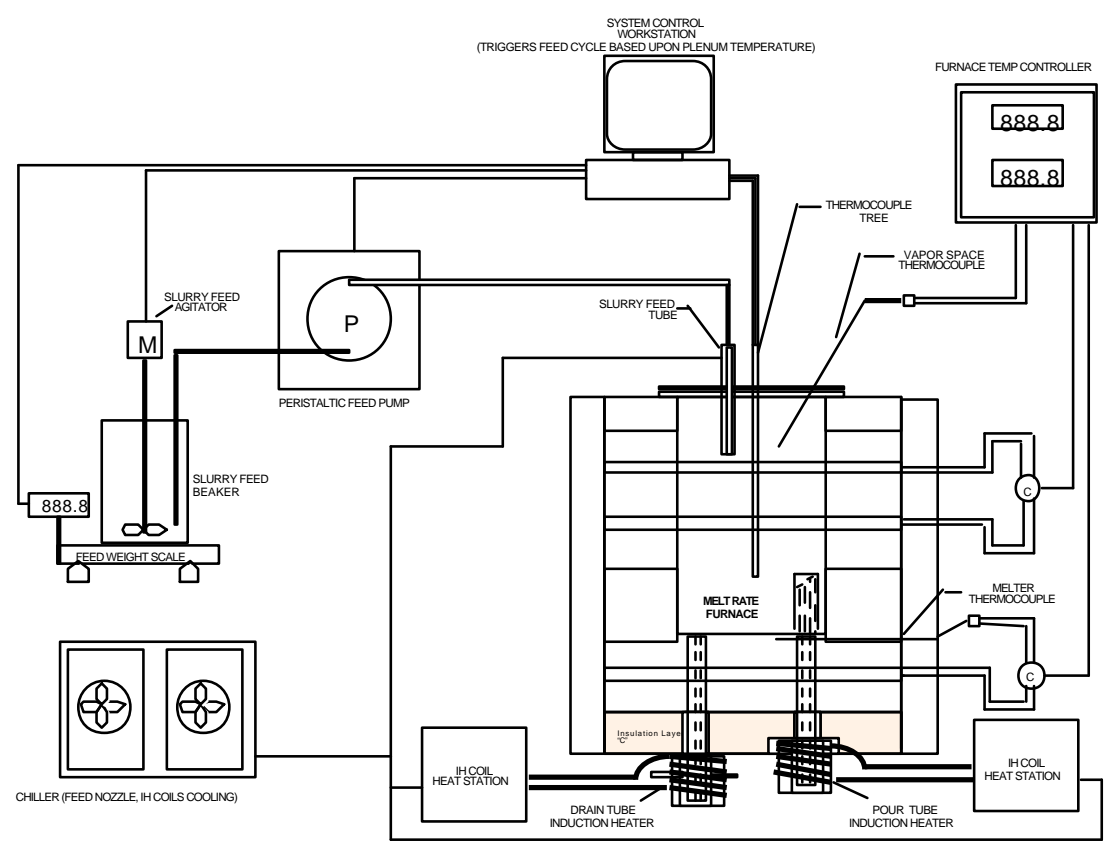


The two systems are identical with the exception of the melt pool depth and the method of heating the pour/drain tubes. The CETL SMRF has an 8" melt pool depth and a propane torch heats the pour/drain tubes. The ACTL SMRF has a 4" pool depth and induction coils heat the pour/drain tubes. The glass temperature is controlled by a thermocouple mounted on the bottom of the crucible and for these tests the setpoint was maintained between 1125 and $1175^{\circ} \mathrm{C}$. Additional heating was applied to the plenum above the melt pool by Globar heaters that surround the top of the crucible. The plenum temperature was controlled from a thermocouple inserted into the vapor space of the crucible, and by changing the setpoint, different plenum conditions could be simulated. Feed additions to the melter were based on maintaining a plenum temperature set point: After each feed cycle, the controller waited for the melter to return to the vapor space set point temperature (typically between 600 and $800^{\circ} \mathrm{C}$ ). Once the vapor space temperature setpoint was reached and the temperature was increasing, the feed cycle began again. As slurry was fed onto the melt surface, glass was continuously poured from the SMRF through the overflow pour tube. The break-over level for glass pouring from the SMRF required 3-1/2 inches of glass depth in the ACTL crucible and 8 inches in the CETL crucible. The poured glass was collected in a catch pan located beneath the pour tube discharge and was weighed. Melt rate was assessed by weighing the amount of glass poured over the test period and by measuring the mass decrease of the feed vessel over the test period.

The bubbler tests were conducted by feeding the slurry in controlled increments to the SMRF for a sufficient time to establish the cold cap and reach steady operation, which typically was about two hours. Melt rate data and observations relating to melting, cold cap, and feed behavior were then obtained.

\subsection{Testing Details}

\subsection{ACTL Bubbler Tests - Frit 320/Sludge Batch 2 (SB2) Feed}

The mini-bubbler runs in the ACTL SMRF for Frit 320 and Frit 200 are summarized in Table 2 and are discussed in detail below.

Table 2 ACTL SMRF Melt Rate Tests with SB2

\begin{tabular}{|c|c|c|c|c|c|c|}
\hline DATE & Feed Type & $\begin{array}{c}\text { Feed Solids } \\
(\mathrm{Wt} \%)\end{array}$ & $\begin{array}{c}\text { Bubbler Air } \\
\text { Flow } \\
(\mathrm{scc} / \mathrm{min})\end{array}$ & $\begin{array}{c}\text { Vapor Space } \\
\text { Temperature } \\
\left({ }^{\circ} \mathrm{C}\right)\end{array}$ & $\begin{array}{c}\text { Avg. Feed } \\
\text { Rate } \\
(\mathrm{grams} / \mathrm{min})\end{array}$ & $\begin{array}{c}\text { Avg. Glass } \\
\text { Pour Rate } \\
(\mathrm{grams} / \mathrm{min})\end{array}$ \\
\hline $7 / 22 / 02$ & Frit 320 & 40 & 35 & 750 & $40.8^{*}$ & $10.5^{*}$ \\
\hline $7 / 30 / 02$ & Frit 320 & 40 & 0 & 750 & 42.9 & 13.7 \\
\hline $7 / 31 / 02$ & Frit 320 & 40 & 15 & 750 & 49.2 & 14.9 \\
\hline & & & & & & $9.6^{* *}$ \\
\hline $8 / 07 / 02$ & Frit 200 & 41 & 0 & 750 & $48.9^{* *}$ & NA \\
\hline $8 / 08 / 02$ & Frit 200 & 41 & 15 & 1750 & $50.2^{* *}$ & 9.2 \\
\hline
\end{tabular}

* Cold cap and steady state feeding/melting not established due to interruptions caused by feed tube pluggage. Melt rate number not reliable.

** Presence of thick cold cap ( $>1$ inch) - evidence of over feeding melter 
The initial, mini airlift bubbler tests were conducted in the ACTL SMRF using Frit 320/SB2 melter feed. The mini-bubbler used is shown in Figure 5 and is a simplification of the larger airlift bubbler under development for the DWPF melter. The mini-bubbler consists of a $1 / 4$ inch Inconel 690 tube welded to a $3 / 4$ inch ID Inconel 690 pipe (draft tube). Air enters the $1 / 4$ inch tube and is discharged through two $1 / 32$ inch diameter holes spaced at $120^{\circ}$ and located $1 / 2$ inch from the bottom of the draft tube. The resulting air bubbles pump glass upward through the $3 / 4$ inch draft tube and discharged it out the top. For this test the bubbler was positioned vertically about $1 / 4$ inch below the glass surface (glass/cold cap interface) and at the location shown in the SMRF plan view of Figure 6 . A bubbler flow rate of $35 \mathrm{scc} / \mathrm{min}$. was used for this test.

\section{Figure 5. Original SMRF Bubbler Design}

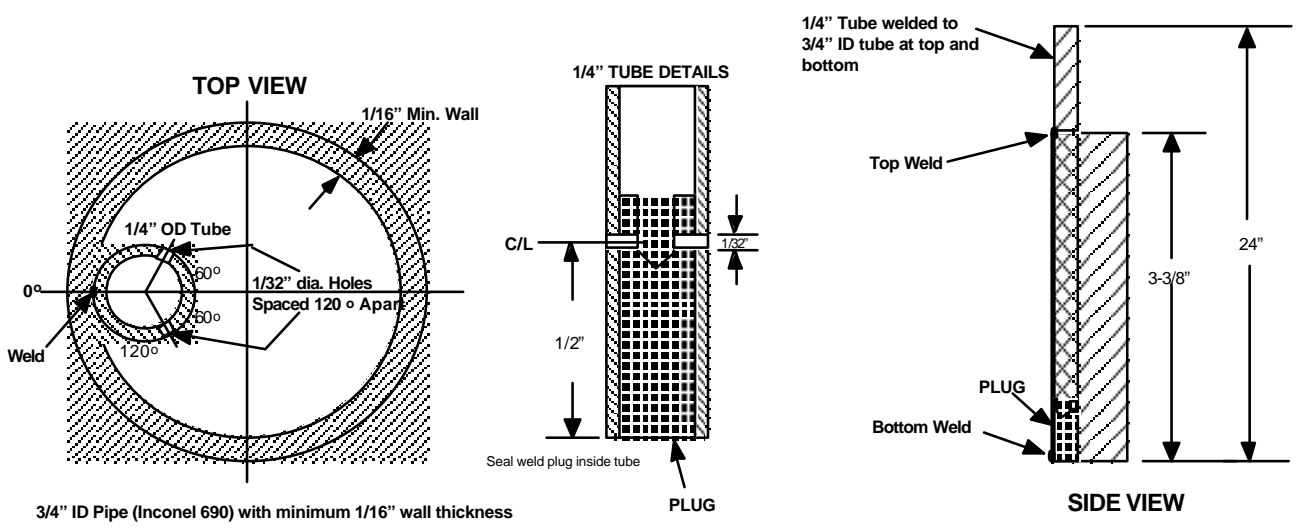

Figure 6. Bubbler Location - SMRF Plan View

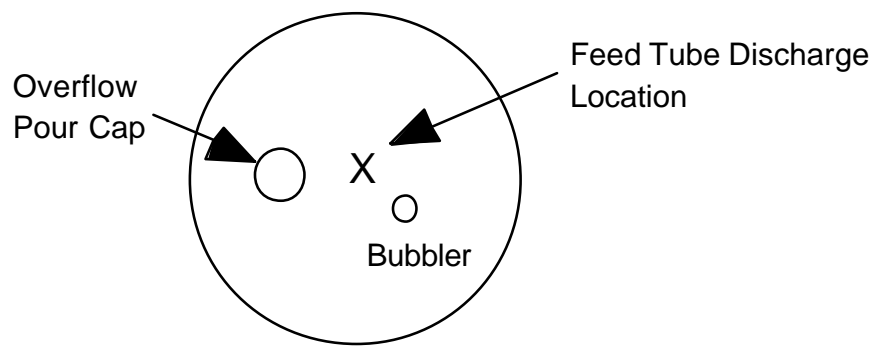

For the initial 35 minutes of feeding, the glass could be observed discharging from the top of the bubbler, although the flow appeared to be lower than expected based on mini-bubbler tests conducted in glycerin. At the 35-minute mark, however, the slurry feed covered the vent hole and the cold cap that formed obscured the bubbler. No vent hole was visible above the bubbler for the remainder ( $4 \frac{1}{2}$ hours) of the test. Two feed tube plugs were experienced during the run which prevented extended feeding operation that is required to attain a steady operating condition and generate good melt rate information. The cumulative amount fed, the feed rate, and the pour rate as a function of run time are shown in Figure 7. 


\section{Figure 7. Frit 320/SB2 Run With Bubbler - 7/22/2002}

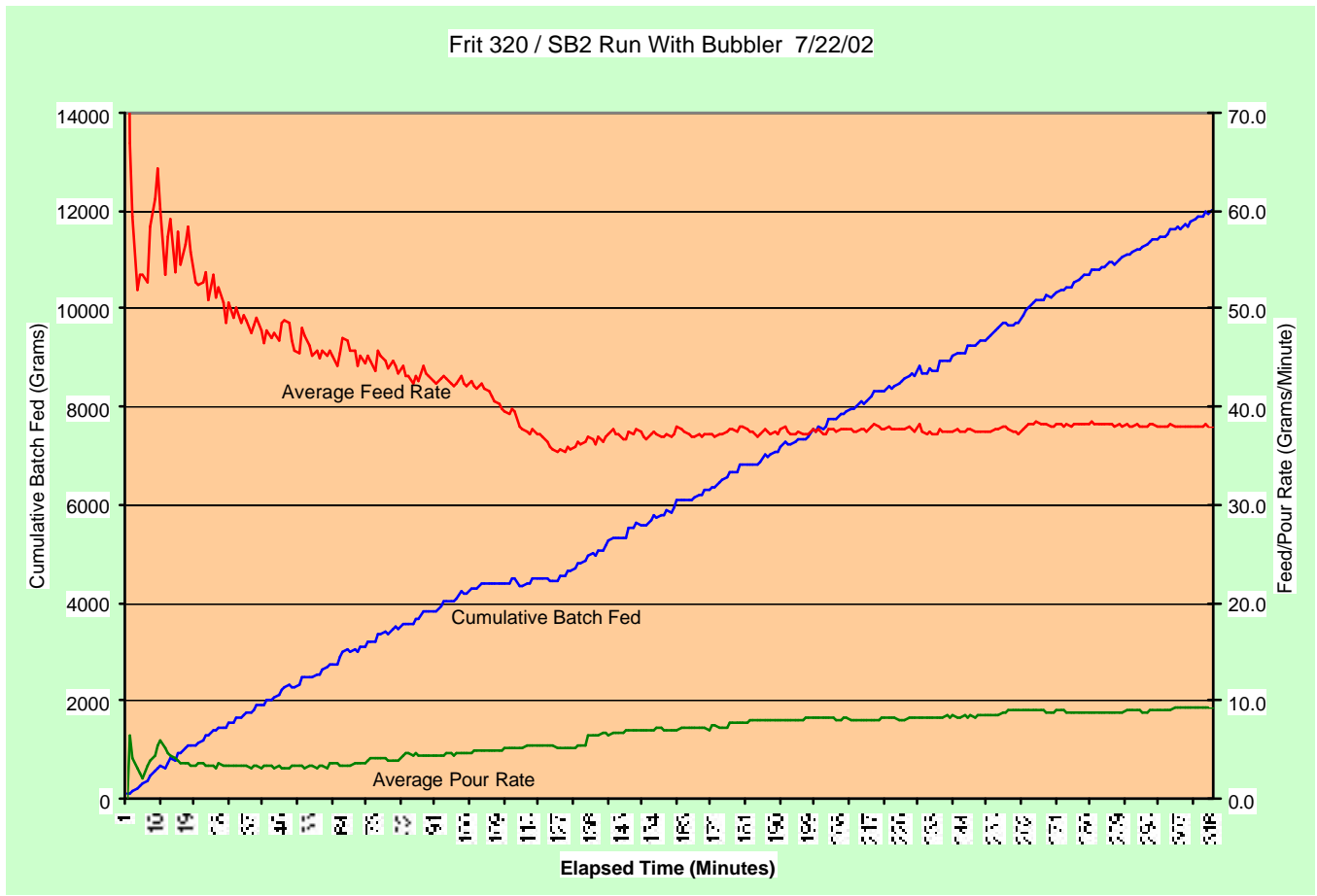

As a result of the problems experienced during this run two changes were made to the SMRF, one to the feed tube and the other to the bubbler. The water-cooled feed tube was replaced with another feed tube with a larger inside diameter ( $0.187 \mathrm{vs} .0 .094$ in the original tube) to reduce the potential for pluggage. In an effort to increase the glass discharge flow from the bubbler, an additional 1/16-inch diameter discharge hole was added to the bottom of the mini-bubbler air supply tube as shown in Figure 8. The two 1/32-inch holes were not altered. These changes were made based on the observed differences in bubble behavior between the glycerin and actual glass tests. The bubbles observed with the glycerin tests filled the internal diameter of the bubbler discharge tube, providing a hydraulic lift effect on the glycerin as the bubble rose within the tube. Prior to the air supply tube modification, the bubbles that formed within the bubbler discharge tube were too small to fill the entire internal diameter of the bubbler. Increasing the air flow to the bubbler only produced additional small bubbles, but still did not provide bubbles large enough to fill the internal diameter of the discharge tube. The additional discharge hole added to the bottom of the bubbler air supply tube provided sufficient air to create bubbles large enough to fill the entire diameter of the bubbler tube, thus improving the hydraulic lift effect upon the glass within the bubbler tube. 
Figure 8. Modified SMRF Bubbler Design

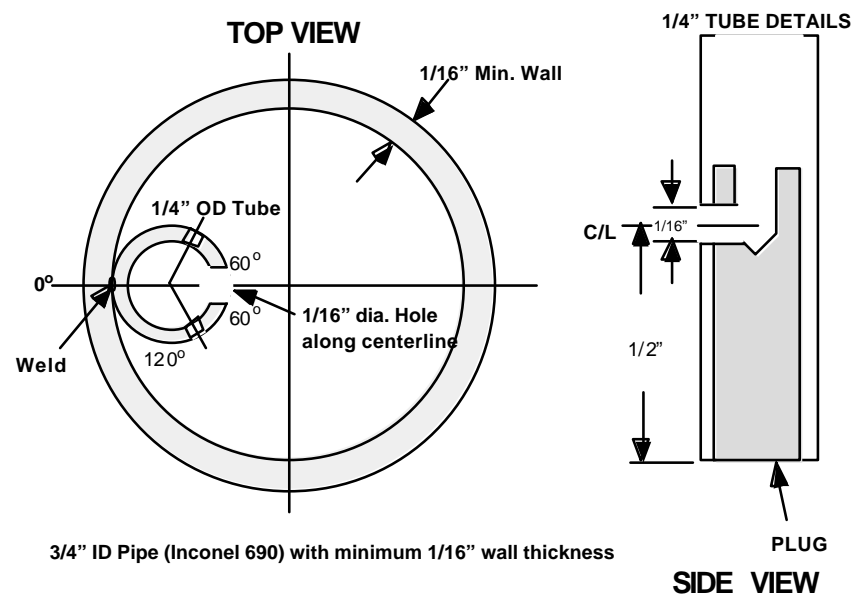

The feed tube change was subsequently evaluated in a Frit 320/SB2 baseline (no mini-bubbler) run. The SMRF setpoint temperatures remained unchanged and controlled the melt pool at $1125^{\circ} \mathrm{C}$ and the vapor space at $750^{\circ} \mathrm{C}$. Slurry feeding continued for 497 minutes, with a 32 minute interruption caused by a pour tube heater outage that occurred 117 minutes into the run. Figure 9 provides a plot of cumulative amount fed, feed rate, and pour rate. After establishment of the cold cap approximately 100 minutes into the run, the feed rate averaged 42.9 grams/min. Glass production during the period was $13.7 \mathrm{~g} / \mathrm{min}$. Feed system performance was excellent. No feed tube pluggages were encountered.

The next day a Frit 320 / SB2 SMRF run was performed using the modified mini-bubbler shown in Figure 8. Prior to initiating slurry feeding, the bubbler was installed in the melt pool at an elevation that placed the top of the discharge tube approximately $1 / 4$ inch below the glass surface at the location given in the melter plan view in Figure 6. The airflow to the bubbler was subsequently set to $10,20,30,40$ and $50 \mathrm{scc} / \mathrm{min}$. and the glass discharge flow from the bubbler as well as air bubble dissipation was visually observed at each condition. It was determined by observation of the melt pool surface that the optimal glass movement through the bubbler was achieved between the 10 and $20 \mathrm{scc} / \mathrm{min}$. airflow settings. Therefore, the bubbler airflow was set to $15 \mathrm{scc} / \mathrm{min}$. to begin the melt rate test.

The SMRF was slurry fed for 269 minutes with no feed or glass pouring interruptions. Figure 10 shows the cumulative amount fed and the average feed rate and pour rate as a function of operating time. As seen in previous SMRF runs, approximately 100 to 120 minutes were again required to establish a cold cap and reach a steady feeding condition. The feed rate tapered off near the 240- minute mark because of air entrainment caused by a low level in the feed tank. The feed rate averaged $49.2 \mathrm{~g} /$ minute at steady conditions and glass production during the same period averaged $14.9 \mathrm{~g} /$ minute. Based upon visual observation of the glass discharged from the bubbler and the vent in the cold cap, the larger diameter discharge on the bubbler air supply tube significantly improved bubbler performance. Approximately a 9\% increase in melt rate was observed with the mini-bubbler and melting behavior was acceptable. No problems with bubble dissipation were evident with the Frit 320/SB2 feed. The hot glass that discharged from the 
bubbler maintained a vent hole in the cold cap for the entire run. Even when the slurry feed covered the hole, the vent was readily re-established in a short time period (1 to 2 minutes). The cold cap thickness was between 1 and 1-1/2 inches and the surface was firm and crusty with a somewhat softer under structure. Both SMRF runs were video taped and a photo of the cold cap and vent hole is shown in Figure 11.

Figure 9. Frit 320 / SB2 Run Baseline Run - 7/30/02

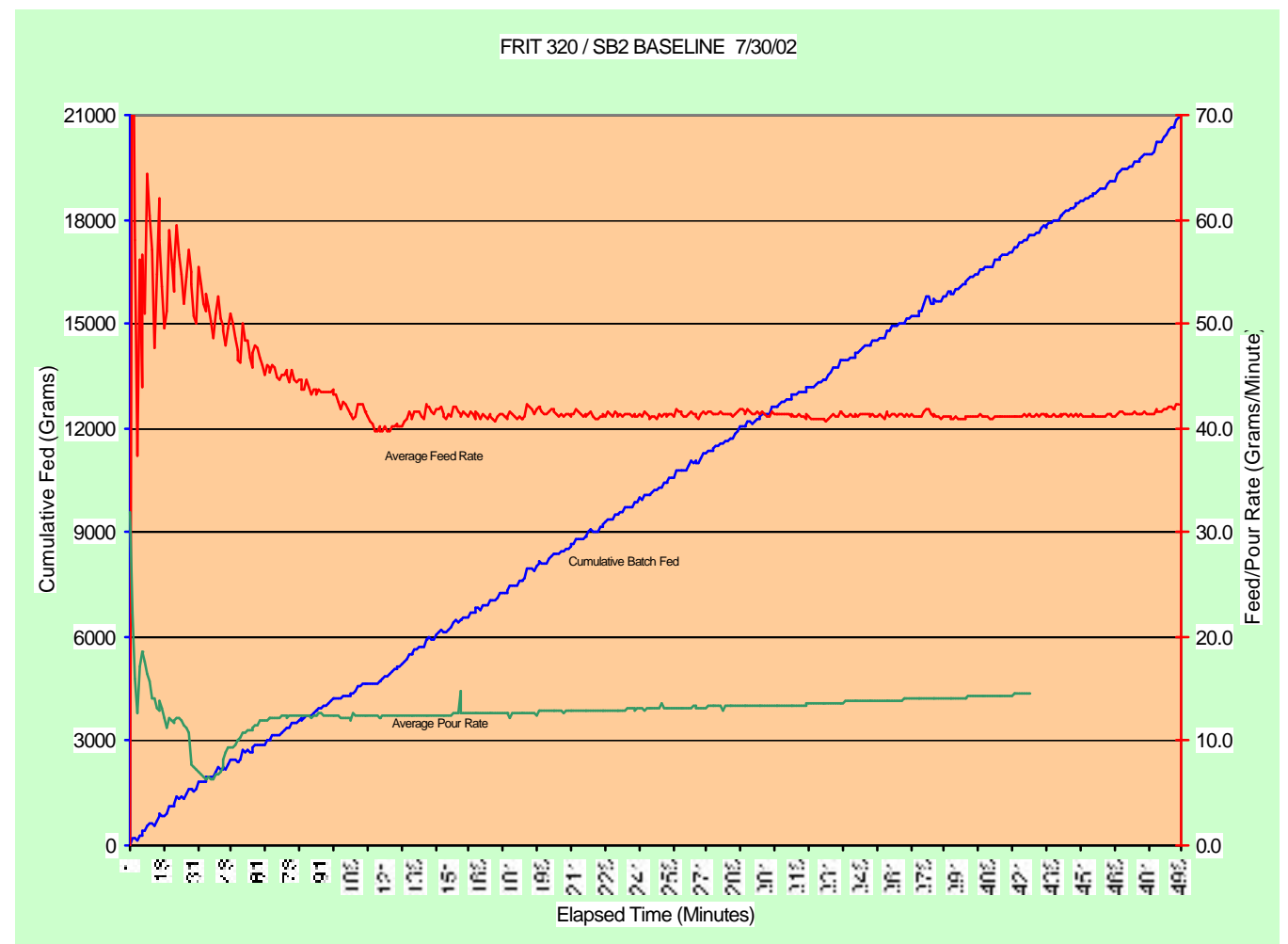


Figure 10. Frit 320 / SB2 Run With Bubbler - 7/31/02

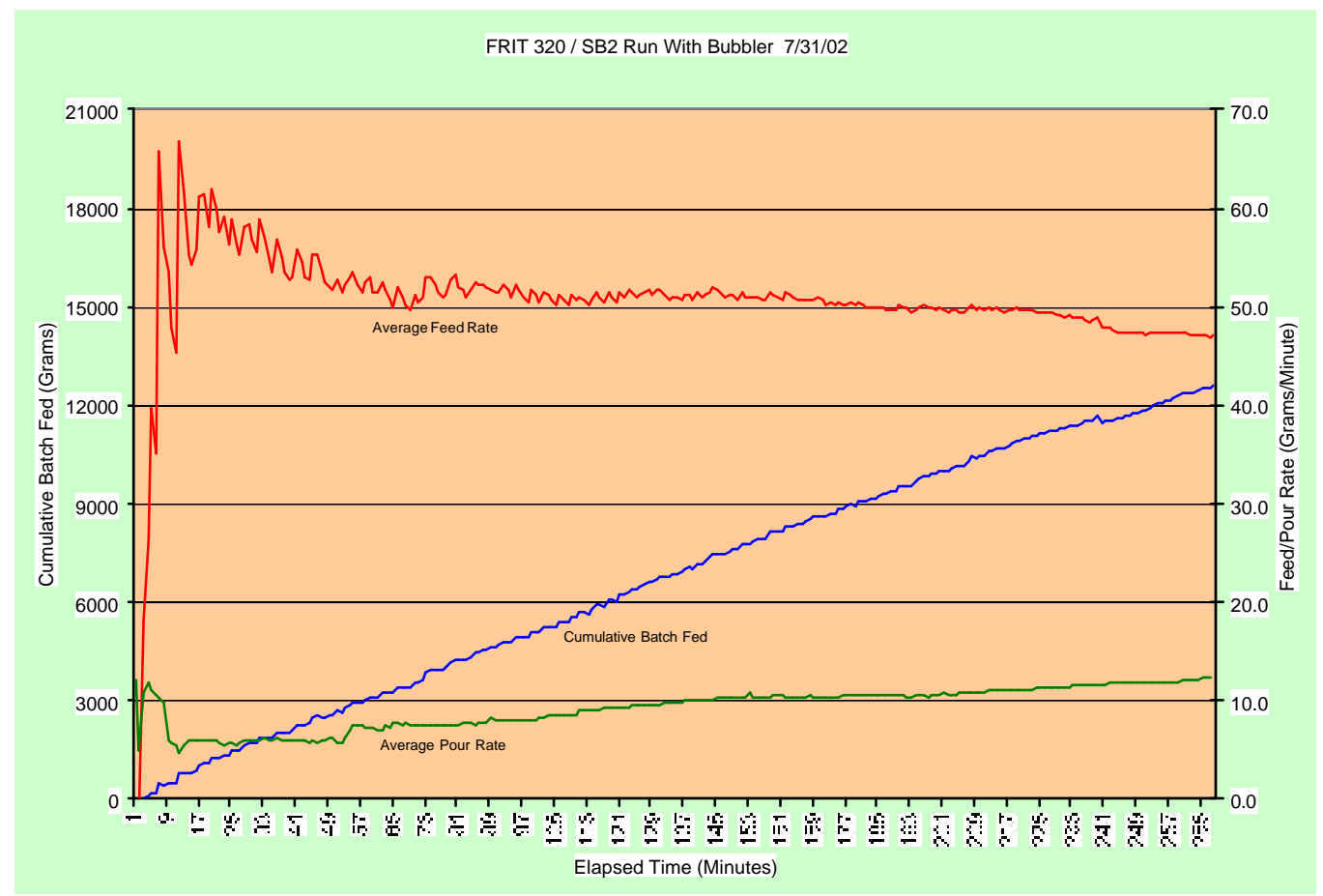

Figure 11. Cold Cap and Vent Hole -Frit 320 / SB2 Run - 7/31/02

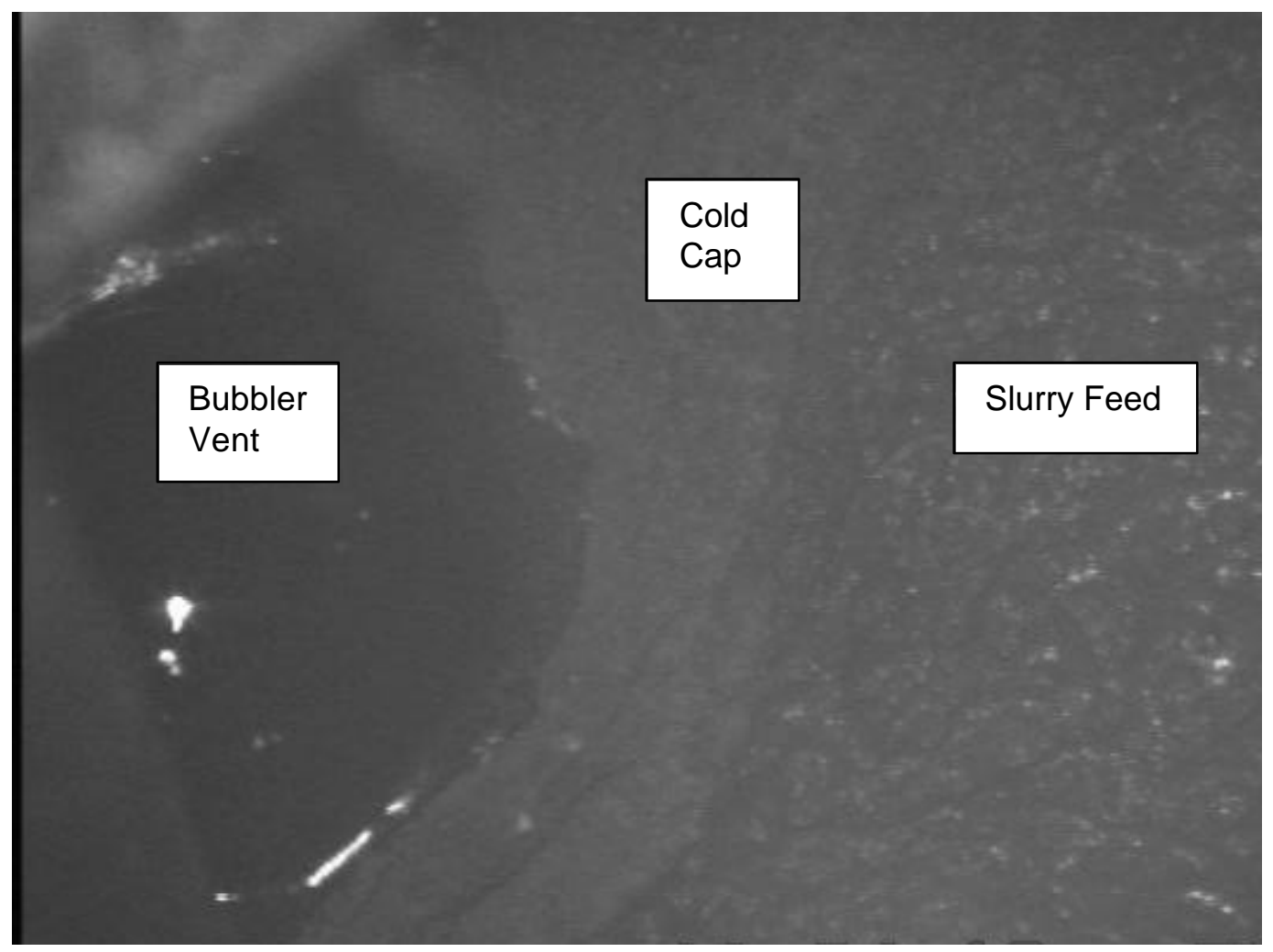




\subsection{ACTL Bubbler Tests - Frit 200/SB2 Feed}

Prior to conducting baseline and mini-bubbler melt rate tests with Frit 200/SB2 feed, the SMRF was drained to remove the Frit 320/SB2 glass and was re-charged with 8,500 grams of black frit that was used in Plutonium can-in-can testing at CETL. The composition of this glass, which is provided in Table 3, was determined to be a better starting composition for Frit 200 testing than the Frit 320/SB2 glass (more viscous).

Table 3. Black Frit Composition

\begin{tabular}{|c|r|}
\hline Component & Wt\% \\
\hline $\mathrm{SiO}_{2}$ & 55.5 \\
\hline $\mathrm{B}_{2} \mathrm{O}_{3}$ & 7.9 \\
\hline $\mathrm{Al}_{2} \mathrm{O3}$ & 6.8 \\
\hline $\mathrm{Fe}_{2} \mathrm{O}_{3}$ & 10.5 \\
\hline $\mathrm{Na}_{2} \mathrm{O}$ & 11.6 \\
\hline $\mathrm{Li}_{2} \mathrm{O}$ & 4.5 \\
\hline $\mathrm{MnO}$ & 1.6 \\
\hline $\mathrm{CaO}$ & 1.6 \\
\hline
\end{tabular}

For the Frit 200/SB2 baseline melt rate test, the SMRF melt pool and vapor space temperatures were maintained at the same setpoints that were used for Frit $320 / \mathrm{SB} 2$ operation, $1125^{\circ} \mathrm{C}$, and $750^{\circ} \mathrm{C}$, respectively. Slurry feeding continued for 295 minutes with no feeding interruptions. Feed rate and pour rate information is shown in Figure 12. As was the case for Frit 320/SB2 feed, approximately 100 minutes were required to establish a cold cap as evidenced by the feed rate plot. The slurry feed rate for the Frit 200 feed $(48.9 \mathrm{~g} / \mathrm{min}$.) was considerably higher than for the Frit 320 feed ( $42.9 \mathrm{~g} / \mathrm{min}$.). Based on cold cap observations, visual inspection, and probing, it appeared that the SMRF was overfed, i.e. the feed rate exceeded the melt rate. A thick crusty cold cap was formed that had a depth that ranged from 2 inches to as much as $31 / 2$ inches. These observations agreed with the low glass production rate $(9.6 \mathrm{~g} / \mathrm{min}$.). Over the time interval from 100 minutes to 300 minutes, 1894 grams of glass were produced versus an expected amount of 3452 grams. Approximately 1558 grams of material were held up in the unmelted rigid cold cap. Thus the apparent feed rate with Frit 200 is not sustainable for longer periods, and the actual feed rate is lower. 
Figure 12. Frit 200 / SB2 Baseline Run - 8/7/02

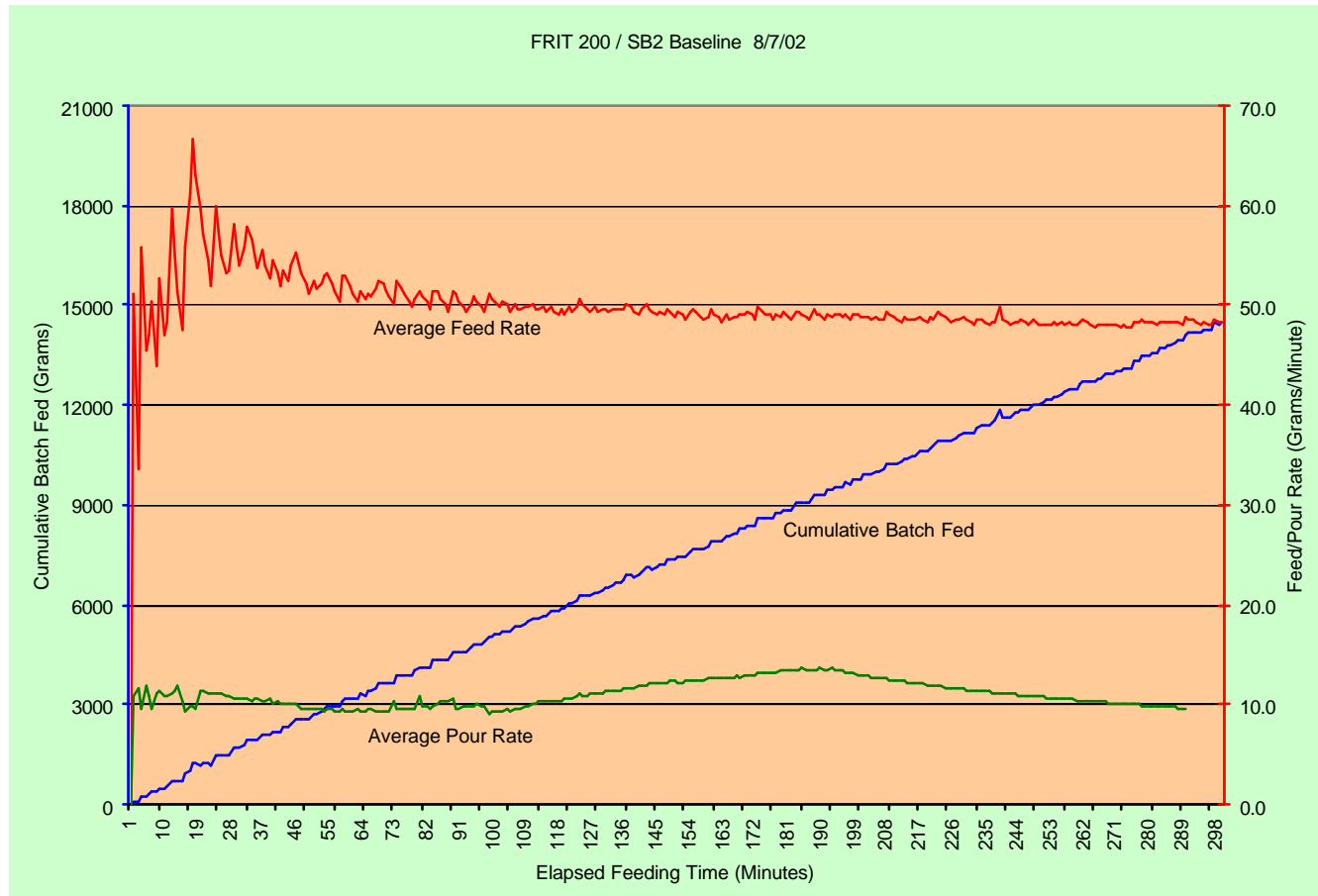

A mini-bubbler test using Frit 200/SB2 feed was conducted next in the SMRF. The bubbler was installed in the same location ( 1/4 inch beneath the glass/cold cap interface) as in the previous tests with Frit 320. Airflow through the bubbler was maintained at $15 \mathrm{scc} / \mathrm{min}$ throughout the entire test. Slurry feeding continued for 337 minutes with no interruptions. Feed rate, pour rate, and cumulative feed information are plotted in Figure 13. As in earlier SMRF runs, about 100 minutes were required to establish a cold cap and steady feeding conditions. The apparent average feed rate $(50.2 \mathrm{~g} / \mathrm{min})$ was comparable to that obtained with Frit 200/SB2 without a bubbler (48.9 g/min), and appeared higher than for Frit 320/SB2 (49.2 g/min with bubbler, 42.9 $\mathrm{g} / \mathrm{min}$ without bubbler), which was not expected. As in the previous Frit 200 run without a bubbler, it appeared that the SMRF was overfed, and so feeding at this rate could not be sustained. A very thick ( 2 to 4 inches) cold cap formed that had a hard, crusty top surface. Bubbler performance was quite different with Frit 200 as compared to the Frit 320 based system. The bubbler vent hole was very quickly covered over with the formation of the cold cap. The hot glass being discharged from the bubbler draft tube was not sufficient to keep the vent open. As a result, the cold cap bridged and the melt pool was pressurized by the bubbler air resulting in significantly more glass being poured than expected (4295 grams poured versus 3635 grams expected). The feed rate with and without a bubbler were essentially the same and the pressurized pour with the bubbler negated obtaining useful information from glass production measurements.

These tests indicate that when feed is based only on current plenum temperature, an overfeeding situation easily occurs with Frit 200, leading to excessive cold cap accumulation and instability in gas venting and glass pouring. 
The bubbler elevation was subsequently raised $1 / 4$ inch putting it at the glass cold cap interface, but it had no effect on opening a vent hole. The thick, crusty cold cap hindered further vertical, upward movement of the bubbler. No discernable melt rate increase was observed when the mini-bubbler was re-located with the Frit 200 based system.

Figure 13. Frit 200 / SB2 Bubbler Run - 8/8/02

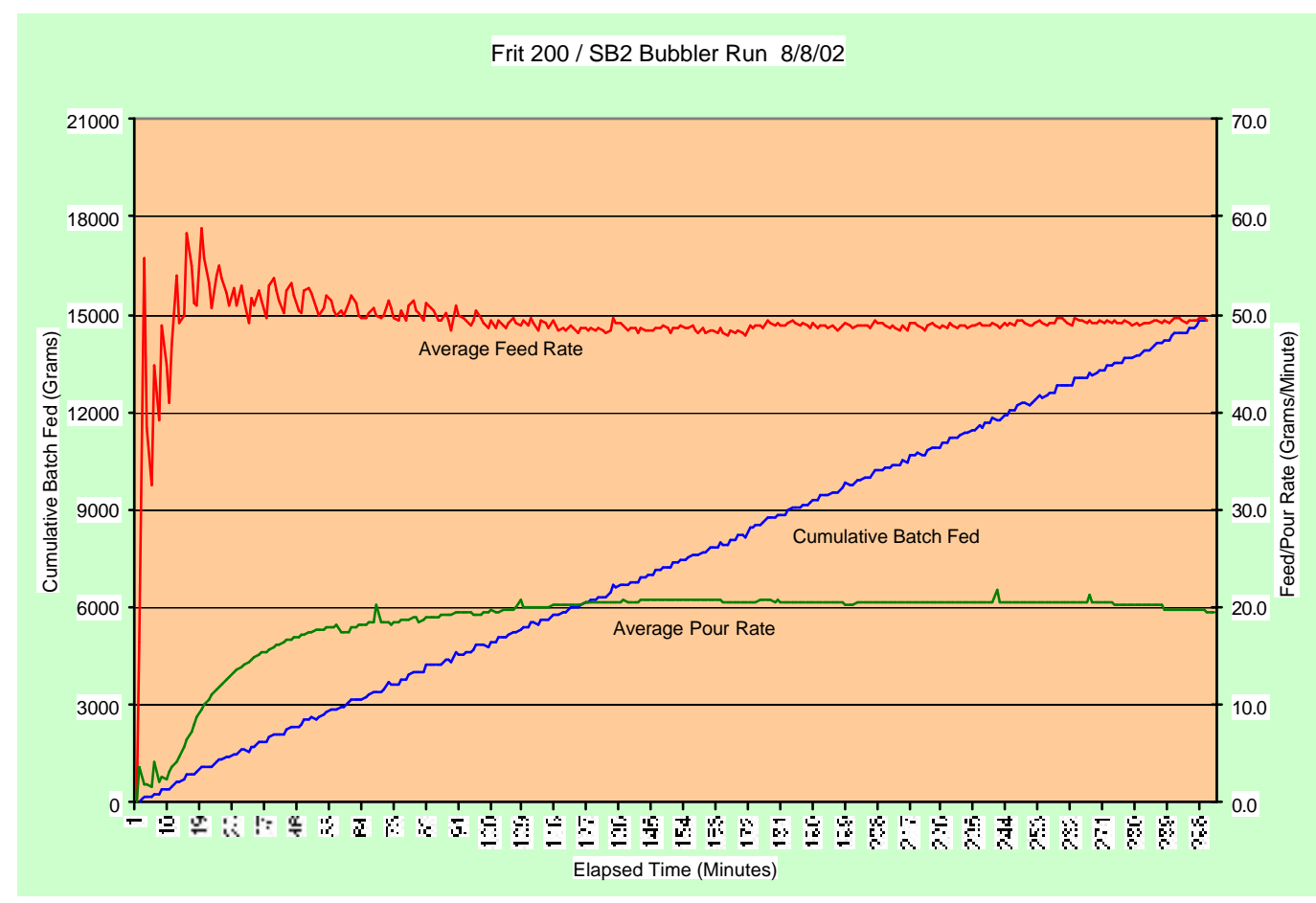

\subsection{CETL Bubbler Tests - Frit 320/SB2 Feed}

A second series of mini-bubbler tests using Frit 320/SB2 melter feed were conducted in the CETL SMRF. SB2 simulant was also used in these CETL runs but the source of the simulant was different. ACTL tests used sludge simulant that had previously been prepared at the University of South Carolina while CETL tests used sludge simulant recently prepared at CETL. A comparison of the compositions (elemental wt\%) is provided in Table 4. Key differences include the aluminum (Al) and sodium (Na) contents. Since direct comparisons between the ACTL SMRF and CETL SMRF melt rates are not made, these composition differences are not expected to affect the results and conclusions. Only relative melt rates are being considered in the current study. Waste loading for the CETL tests was $30 \mathrm{wt} \%$ (oxide basis) versus $25 \mathrm{wt} \%$ for the ACTL SMRF tests. Again, there is no impact on the results or conclusions regarding bubbler effectiveness since only relative melt rates are being considered.

The CETL SMRF has an eight-inch deep melt pool and therefore, permits the evaluation of a longer bubbler draft tube. The longer draft tube was expected to increase glass pumping capability which may further increase melt rate depending on the behavior of the cold cap 
thermal resistance and foam layer. The mini-bubbler used is shown in Figure 14 and is identical to the one used in the ACTL SMRF tests (see Figure 8) except for a longer draft tube length (7" vs. $3-3 / 8$ ").

Table 4. SMRF SB2 Feed Compositions Before Frit Addition

\begin{tabular}{|c|c|c|}
\hline $\begin{array}{c}\text { Element } \\
\mathrm{Wt} \%\end{array}$ & $\begin{array}{c}\text { ACTL SB2 } \\
\text { SRAT } \\
\text { Product }\end{array}$ & $\begin{array}{c}\text { CETL SB2 } \\
\text { SRAT } \\
\text { Product }\end{array}$ \\
\hline $\mathrm{Al}$ & 7.16 & 14.7 \\
\hline $\mathrm{Ba}$ & 0.19 & 0.40 \\
\hline $\mathrm{Ca}$ & 2.46 & 3.56 \\
\hline $\mathrm{Cr}$ & 0.11 & 0.40 \\
\hline $\mathrm{Cu}$ & 0.13 & 0.25 \\
\hline $\mathrm{Fe}$ & 24.3 & 24.0 \\
\hline $\mathrm{K}$ & 0.18 & 0.13 \\
\hline $\mathrm{La}$ & $<0.01$ & $<0.01$ \\
\hline $\mathrm{Mg}$ & 0.10 & 0.24 \\
\hline $\mathrm{Mn}$ & 2.42 & 2.95 \\
\hline $\mathrm{Na}$ & 8.98 & 12.1 \\
\hline $\mathrm{Ni}$ & 1.34 & 1.04 \\
\hline $\mathrm{Pd}$ & 0.08 & $<0.01$ \\
\hline $\mathrm{Rh}$ & 0.04 & $<0.01$ \\
\hline $\mathrm{Ru}$ & 0.33 & $<0.01$ \\
\hline $\mathrm{Si}$ & 0.14 & 1.64 \\
\hline $\mathrm{Zn}$ & 0.24 & 0.48 \\
\hline $\mathrm{Zr}$ & 0.01 & 1.47 \\
\hline & & \\
\hline
\end{tabular}


Figure 14. CETL Mini-Bubbler

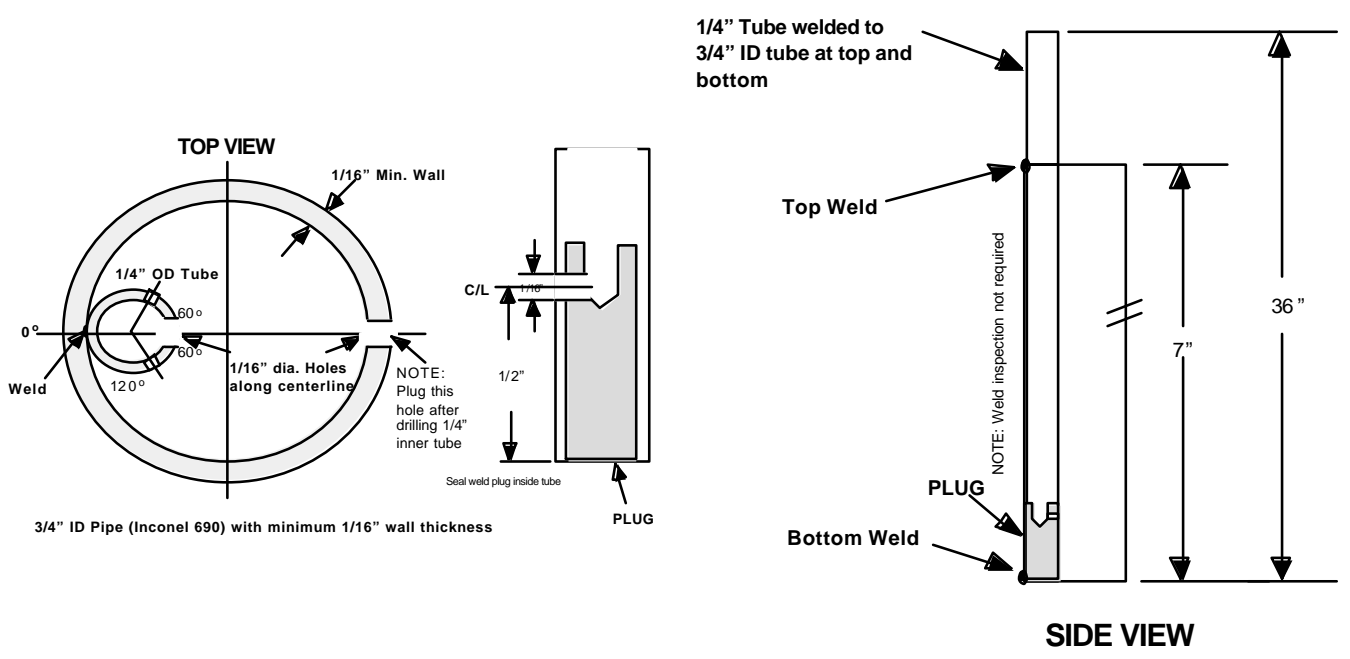

The CETL SMRF runs are summarized in Table 5 and are discussed in more detail in the sections that follow. Both baseline (no bubbler) and mini-bubbler runs were conducted for the different operating parameters (wt\% solids and vapor space temperature) shown in the table. For most of these tests the bubbler was positioned vertically at the glass/cold cap interface and a bubbler air flow rate of $5 \mathrm{scc} / \mathrm{min}$ was used. For the last SMRF mini-bubbler run, the bubbler was positioned to discharge approximately $1 / 4$ " above the glass surface and a bubbler air flow of $25 \mathrm{scc} / \mathrm{min}$ was used. The spatial position of the bubbler was as shown in the SMRF plan view of Figure 6. To allow for the deeper melt pool the control point for the glass pool was raised to $1180^{\circ} \mathrm{C}$, based on $1150^{\circ} \mathrm{C}$ measured temperature at the crucible bottom / glass interface.

Table 5. CETL SMRF Melt Rate Tests

\begin{tabular}{|c|c|c|c|c|c|}
\hline DATE & $\begin{array}{c}\text { Feed } \\
\text { Solids } \\
(\mathrm{Wt} \%)\end{array}$ & $\begin{array}{c}\text { Bubbler Air } \\
\text { Flow } \\
(\mathrm{scc} / \mathrm{min})\end{array}$ & $\begin{array}{c}\text { Vapor Space } \\
\text { Temp } \\
\left({ }^{\circ} \mathrm{C}\right)\end{array}$ & $\begin{array}{c}\text { Average Batch } \\
\text { Feed Rate* } \\
(\text { grams/min })\end{array}$ & $\begin{array}{c}\text { Average Glass } \\
\text { Pour Rate* } \\
\text { (grams/min) }\end{array}$ \\
\hline $8 / 30$ & 52 & 0 & 750 & 32.3 & 12.8 \\
\hline $9 / 3$ & 52 & 5 & 750 & 34.8 & 17.8 \\
\hline $9 / 4$ & 41 & 5 & 650 & 30.5 & 11.2 \\
\hline $9 / 4$ & 41 & 0 & 650 & 27.1 & 9.8 \\
\hline $9 / 4$ & 41 & 0 & 750 & $46.0^{* *}$ & $18.3^{* *}$ \\
\hline $9 / 5$ & 41 & 5 & 750 & 48.9 & 17.7 \\
\hline $9 / 27$ & 41 & 0 & 750 & 42.4 & 15.8 \\
\hline $9 / 30$ & 41 & 25 & $750-893^{* * *}$ & $57.1^{* * *}$ & $18.9^{* * *}$ \\
\hline
\end{tabular}

* Feed Rate and Pour Rate averages represent values after the initial 100 minutes of operation to assure steady conditions were established

** Insufficient operating time allotted to reach steady operating conditions and establish melt rate information $* * *$ Vapor space power set at $100 \%$ output - no direct temperature control 


\subsubsection{High Batch Solids Runs - CETL SMRF}

The first two tests in the CETL SMRF were completed using a $52 \mathrm{wt} \%$ solids, Frit 320/SB2 feed, the maximum solids content that could be reliably pumped with the feed system. The higher solids loading was a departure from the nominal $41 \mathrm{wt} \%$ solids slurry used in melt rate testing in the ACTL SMRF. The tests intended to evaluate at high solids loading the hypothesis that lower water content results in lower heating requirement and higher melt rates. Tests both with and without a mini-bubbler were performed to compare melt rate and melting behavior.

Feed distribution of the $52 \mathrm{wt} \%$ solids feed over the melt pool surface was definitely a problem. As the feed was delivered onto the melt pool it mounded directly beneath the feed tube. Subsequent slurry feed additions tended to only further increase the mass of feed solids in the mound. It appeared that the reduced water content of the feed was either absorbed by the feed pile or evaporated by the vapor space energy input, preventing the feed pile from distributing uniformly over the pool surface. The mounding reduced the percent cold cap coverage and hence, the area available for heat transfer. As shown in Table 5, the glass pour rate for the 52 wt $\%$ solids feed was significantly lower than that for a $41 \mathrm{wt} \%$ feed (12.8 for $8 / 30$ run versus 15.8 for $9 / 27$ run, respectively). The apparent melt rate advantage provided by the reduced water content of the higher wt $\%$ solids feed was negated by the inability to transfer energy to the mounded feed pile needed for water evaporation and vitrification. This problem is not limited to a small melter but would be exacerbated and become critical in a larger melter where feed distribution is more important. Feeding and pouring information are shown in Figure 15.

Figure 15. CETL Frit 320 / SB2 Baseline (High Wt\% Solids) Run - 8/30/02

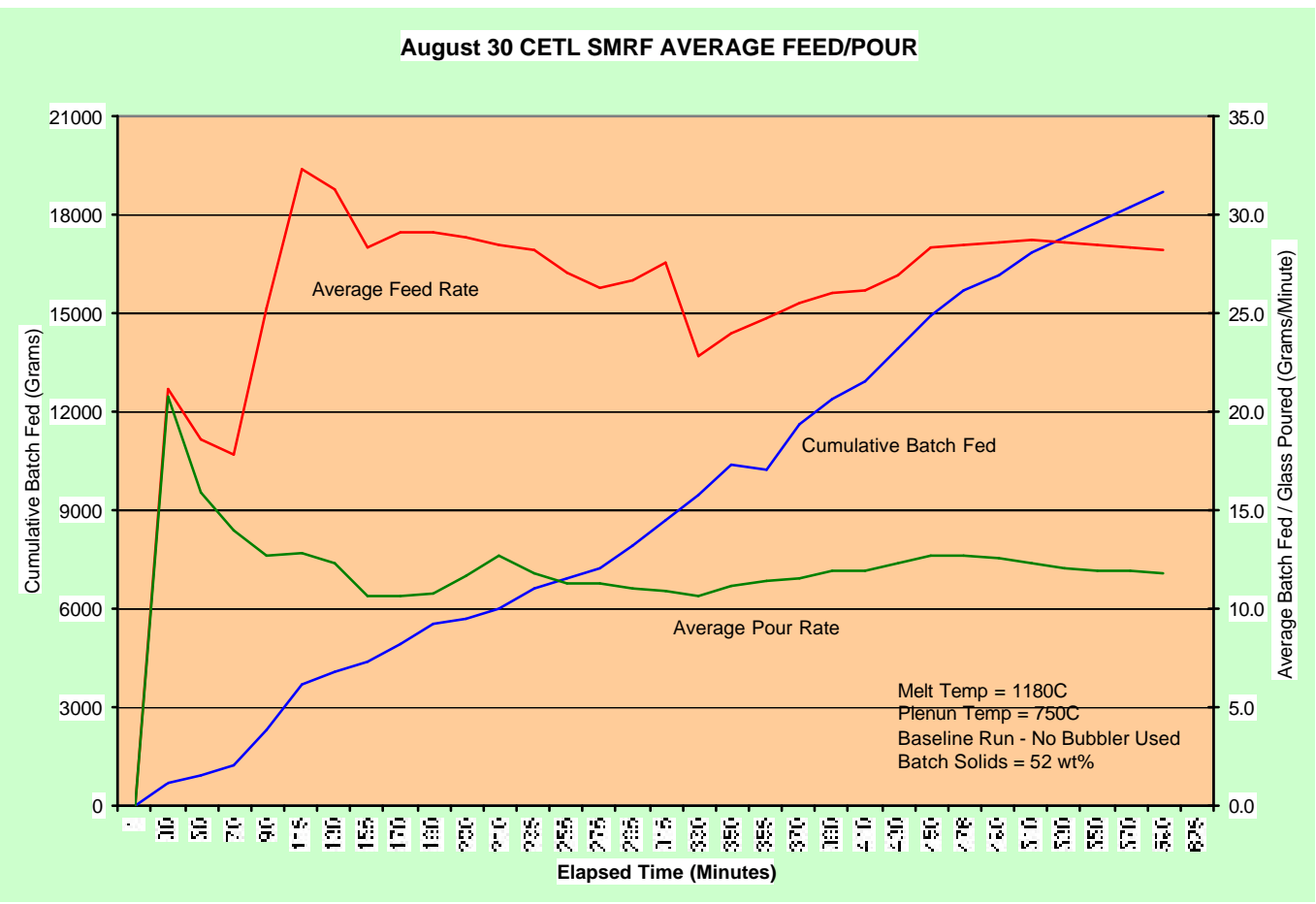


Introducing a mini-bubbler significantly improved the melting rate of the $52 \mathrm{wt} \%$ solids feed. The average glass pour rate increased $39.1 \%$ from 12.8 grams $/ \mathrm{min}$. to $17.8 \mathrm{grams} / \mathrm{min}$. Although the slurry feed still mounded under the feed tube, the bubbler was effective in increasing the cold cap coverage and reducing the height of the mound, all of which led to improved heat transfer. Pour rate and feed rate information are provided in Figure 16.

It should be noted that even though the bubbler significantly increased the melt rate of the high solids feed, the melt rate was only $12.7 \%$ higher than that for a $41 \mathrm{wt} \%$ feed without a bubbler (17.8 grams/min versus 15.8 grams/min for the 9/27 run). Subsequent tests in the CETL SMRF used a $41 \mathrm{wt} \%$ solids feed because of the poor feed distribution at the higher solids loading.

\section{Figure 16. CETL Frit 320 / SB2 Bubbler (High Wt\% Solids) Run - 9/3/02}

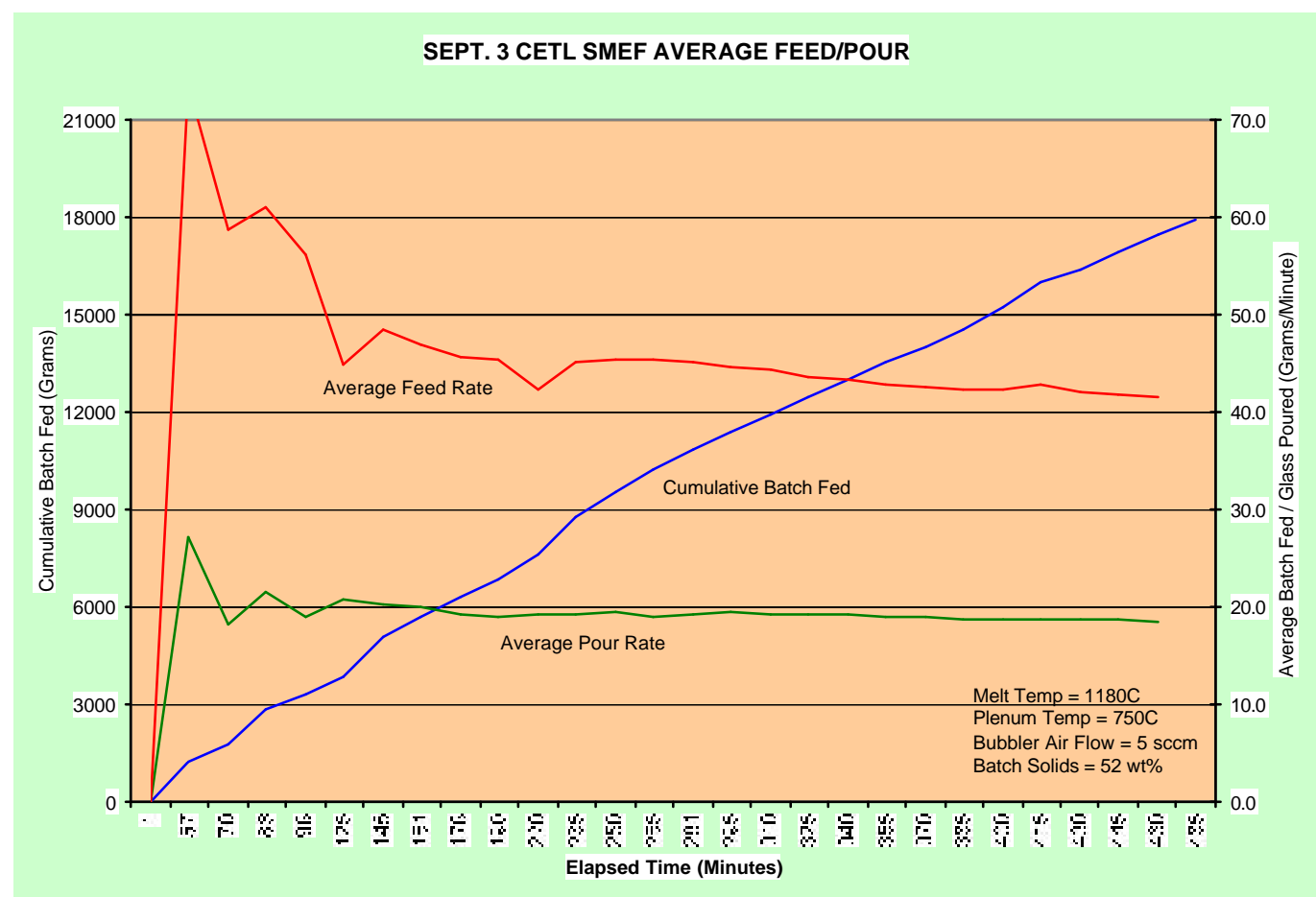

\subsubsection{CETL Lower Plenum Temperature Runs}

The next two runs (on 9/4) evaluated the melt rate and melting behavior of a $41 \mathrm{wt} \%$ slurry at a reduced plenum temperature of $650{ }^{\circ} \mathrm{C}$. The feed sequence initiation temperature was adjusted to $647^{\circ} \mathrm{C}$ for these tests. The mini-bubbler was evaluated in the first run at an airflow rate of 5 scc/min. After 30 minutes of slurry feeding, a 2-1/2 inch thick cold cap formed that appeared to bridge to the melter walls and covered the bubbler discharge vent hole. Discontinuing melter feeding for about 10 minutes eliminated the wall bridging and re-opened the bubbler vent. In an attempt to avoid building cold cap thickness caused by over-feeding, the slurry feed pump speed and cycle duration were reduced. However, when feeding resumed, bridging, increases in cold 
cap thickness, and occlusion of the bubbler vent hole were still observed. This small scale test behavior is not expected to be typical of a full scale installation.

Pour rate and slurry feed rate data are provided in Figure 17 for the lower plenum temperature/bubbler run. After 100 minutes, when steady operating conditions were established, a pour rate of 11.2 grams/min. was demonstrated.

The bubbler was then removed from the SMRF and a baseline run without the bubbler at $650{ }^{\circ} \mathrm{C}$ plenum temperature was made. Figure 17 shows pour rate and feed rate as a function of operating time. The glass pour rate for this baseline run averaged 9.8 grams $/ \mathrm{min}$. Therefore at a $650^{\circ} \mathrm{C}$ plenum temperature, the mini-bubbler provided $14.3 \%$ improvement in melt rate.

Figure 17. CETL Frit 320 / SB2 Low Plenum Temp Run - 9/4/02

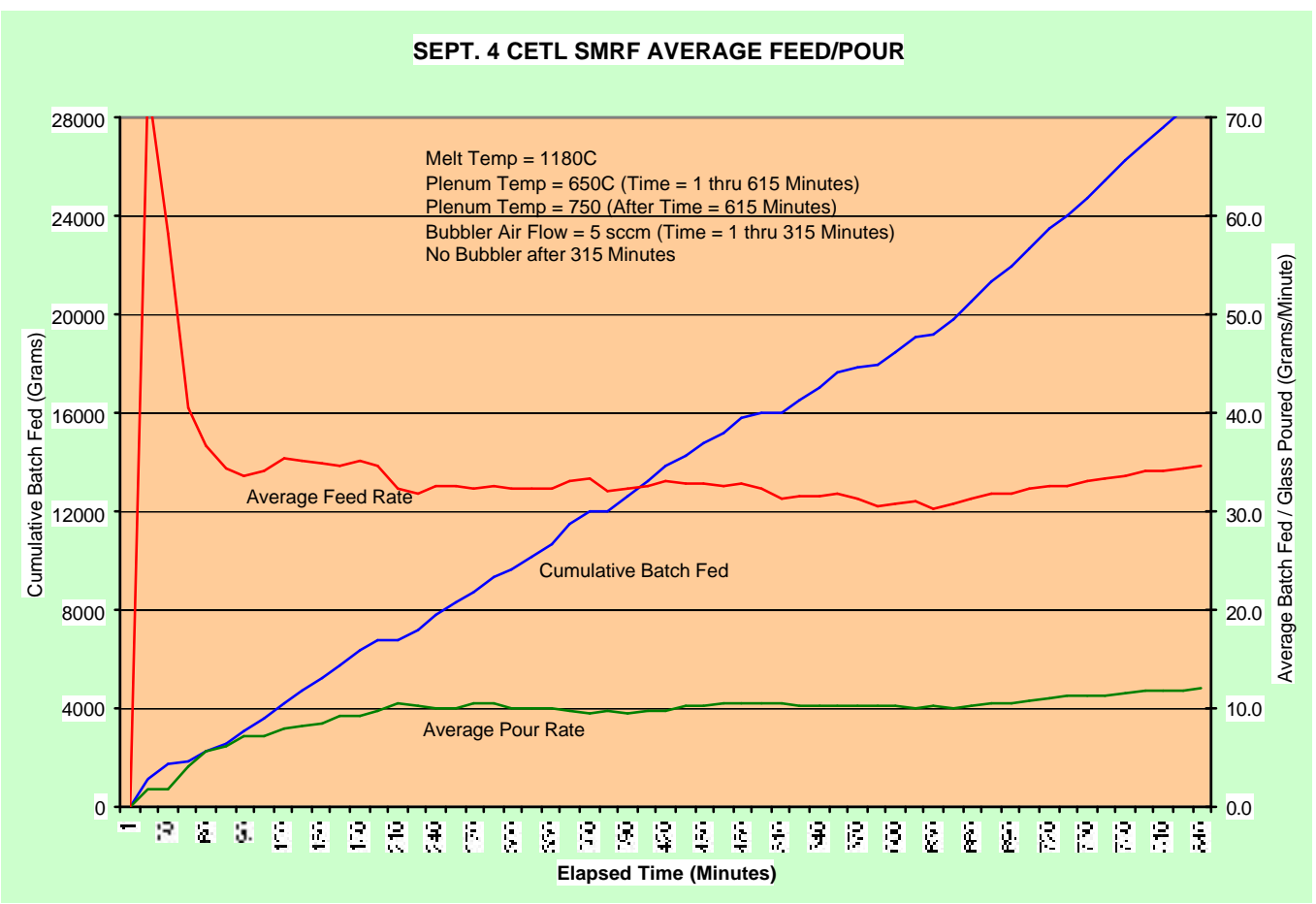

\subsubsection{CETL Standard Batch Solids Runs}

The next three CETL SMRF runs (9/4, 9/5 and 9/27) were designed to evaluate the effect of the bubbler using $41 \mathrm{wt} \%$ solids feed at a $750^{\circ} \mathrm{C}$ plenum temperature. The $9 / 4$ run attempted to transition from a $650{ }^{\circ} \mathrm{C}$ plenum operating temperature to $750{ }^{\circ} \mathrm{C}$ without burning off the cold cap. The data indicates insufficient time was allotted to reach steady operating conditions and, as a result, an erroneously high glass pour rate was achieved. Therefore this test was repeated on 9/27 using the same melter feed and a lower pour rate was attained (15.8 grams/min on 9/27 vs. $18.3 \mathrm{grams} / \mathrm{min}$ on 9/4) confirming earlier concerns that steady operating conditions had not been attained. The $41 \mathrm{wt} \%$ solids feed exhibited much improved flow characteristics. No batch 
solids mounding was observed and the cold cap covered more than $90 \%$ of the melt pool surface. The cold cap thickness was acceptable and appeared to be fairly constant at 1 to 1-1/2 inches.

Introduction of the mini-bubbler at a $750{ }^{\circ} \mathrm{C}$ plenum temperature and with $41 \mathrm{wt} \%$ solids feed improved melt rate by $\sim 12 \%$ from $15.8 \mathrm{grams} / \mathrm{min}$ to $17.7 \mathrm{grams} / \mathrm{min}$. Pour rate and feed rate data for the bubbler and baseline (no bubbler) runs are shown in Figures 18 and 19, respectively.

Figure 18. CETL Frit 320 / SB2 Bubbler Run - 9/5/02

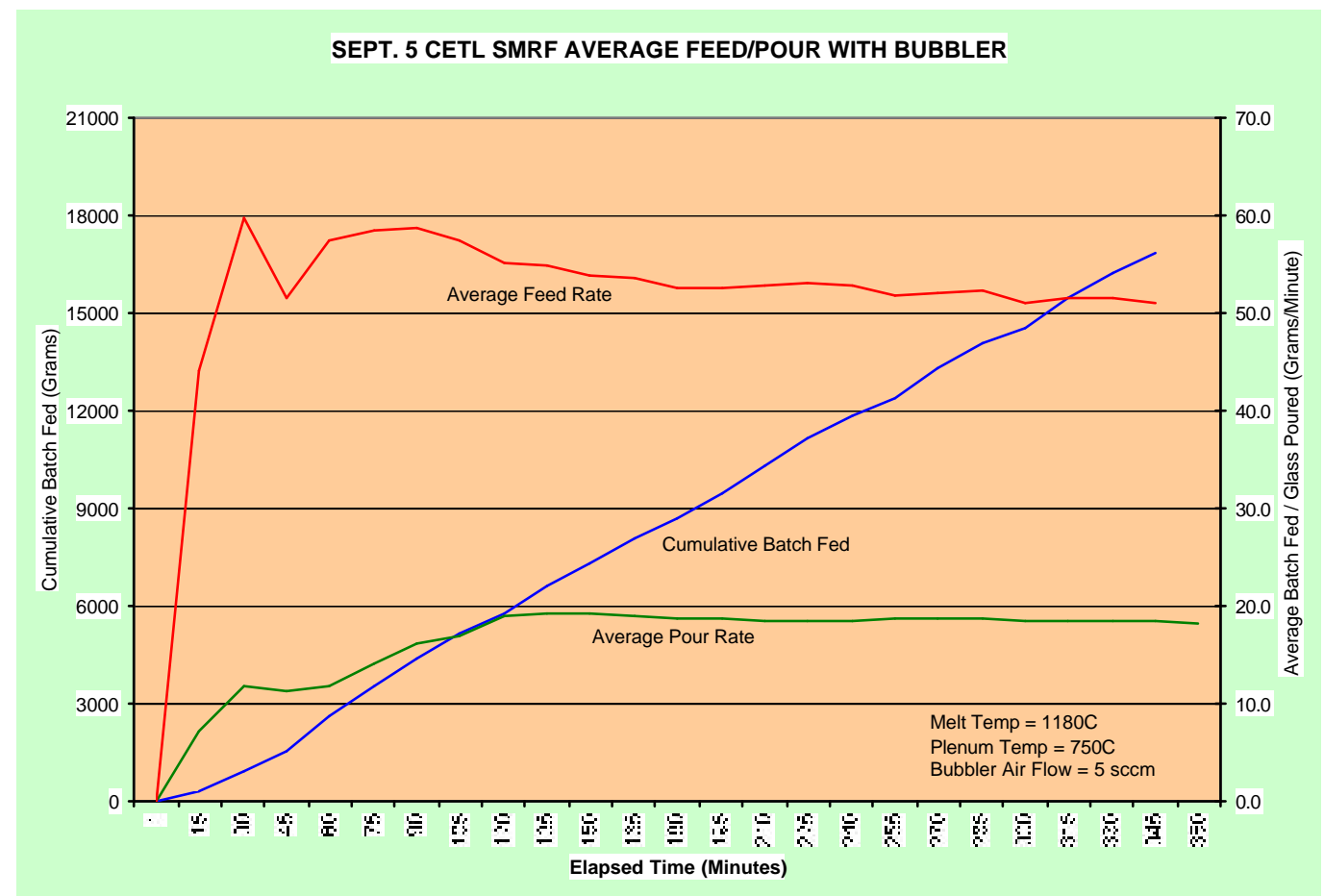


Figure 19. CETL Frit 320 / SB2 Baseline Run - 9/27/02

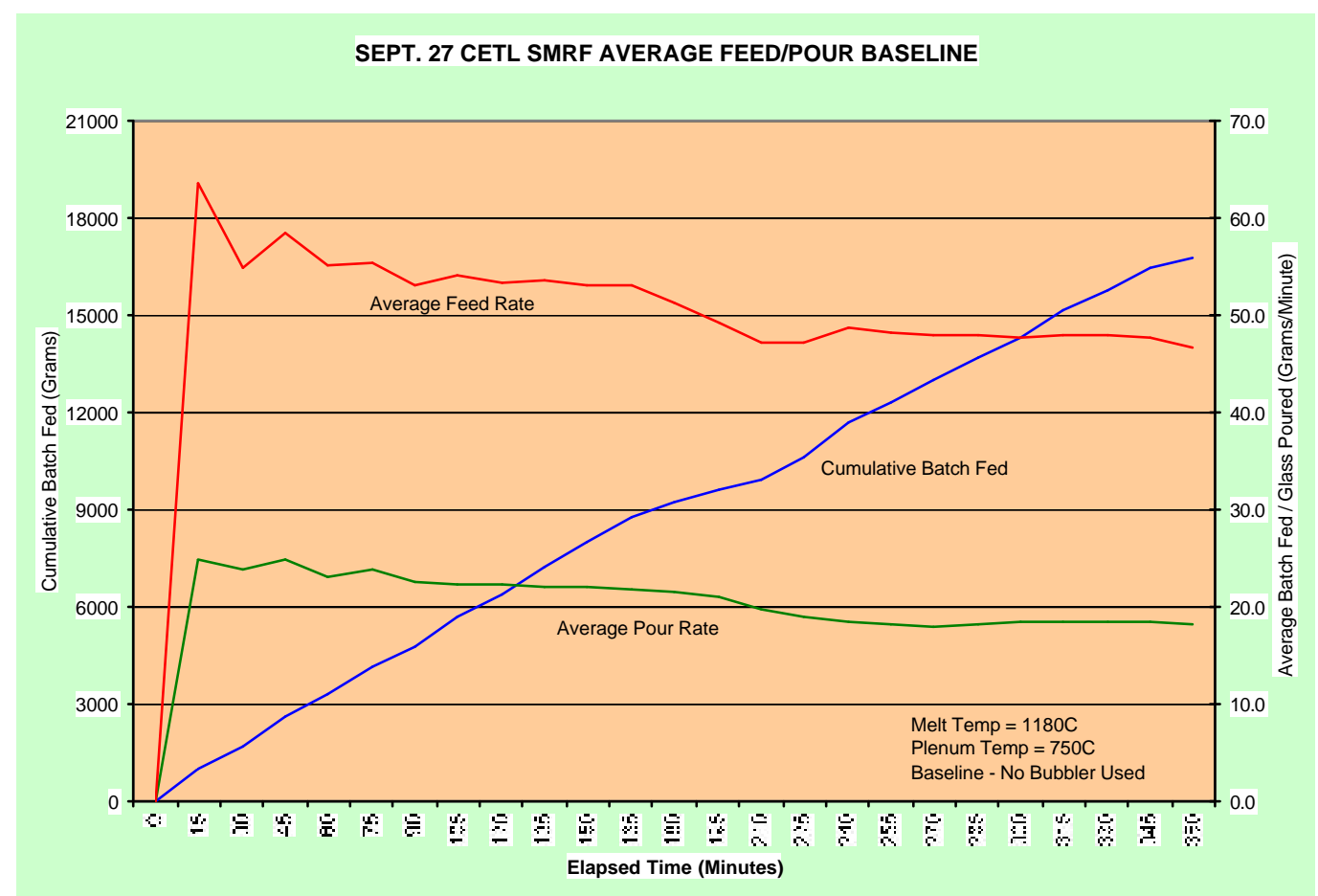

\subsubsection{Modified Bubbler Location - CETL SMRF}

One additional bubbler run was conducted in the CETL SMRF on 9/30 in which three parameters were changed. The vertical elevation of the bubbler was increased so that the top of the draft tube was approximately $1 / 4$ inch above the glass/cold cap interface and the bubbler airflow was increased from 5 to $25 \mathrm{scc} / \mathrm{min}$. In addition, the vapor space (plenum) temperature control was placed in manual mode at $100 \%$ power output. Therefore plenum temperature was limited by the setpoint chosen for the feed initiation sequence, which was $750{ }^{\circ} \mathrm{C}$ for this run. An average glass pour rate of 18.9 grams/min was demonstrated, which represented a $6.8 \%$ increase over the standard bubbler run (on 9/5) at $750{ }^{\circ} \mathrm{C}$ plenum temperature and $5 \mathrm{scc} / \mathrm{min}$ bubbler air flow. Pour rate and feed rate data for modified bubbler run are shown in Figure 20. 
Figure 20. CETL Frit 320 / SB2 Modified Bubbler Run - 9/30/02

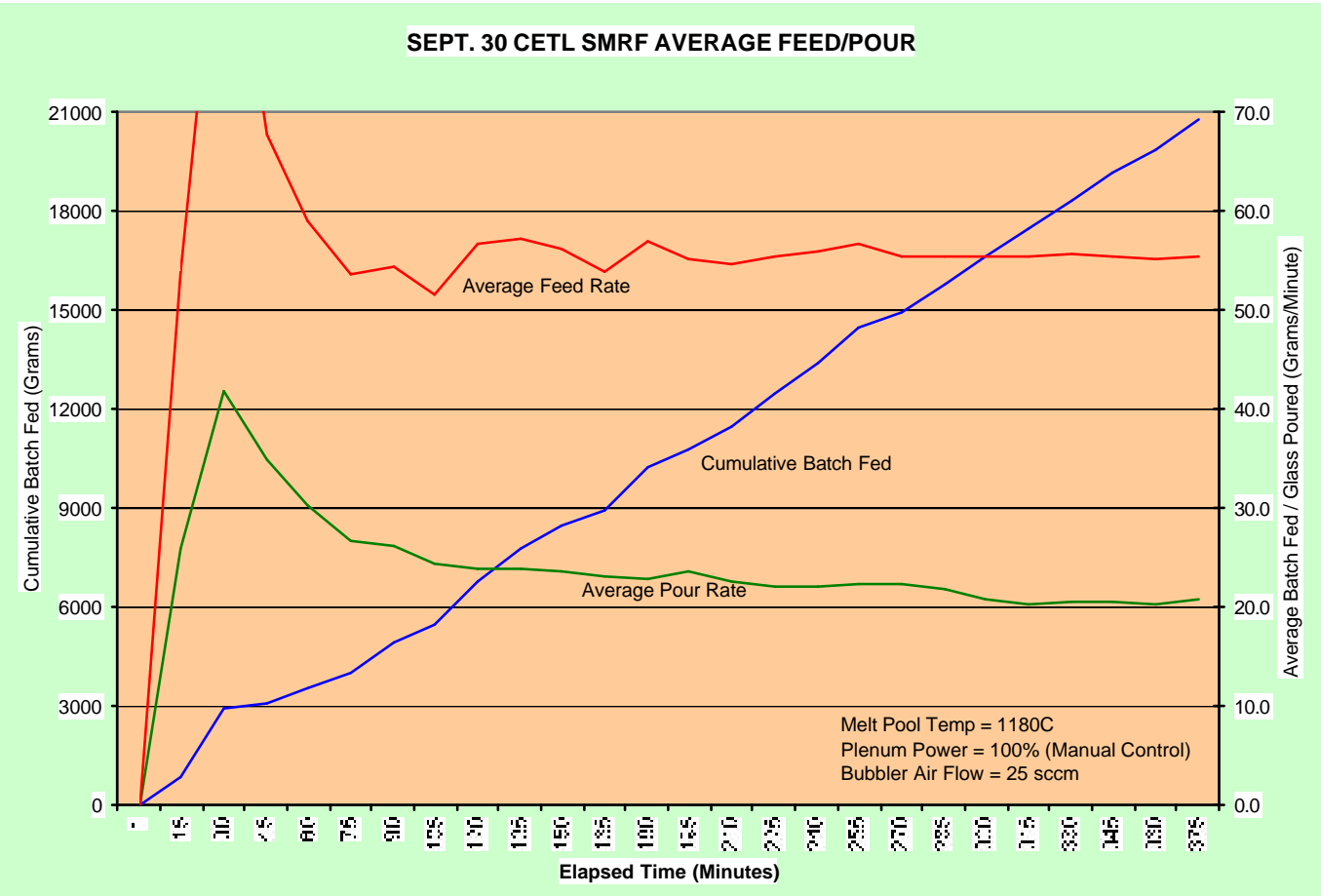

\subsection{Conclusions - Mini-Bubbler Performance with Frit 320 and Frit 200}

Results from the mini-bubbler tests with Frit 320/SB2 are summarized in Table 6. For the ACTL test, the bubbler discharge was positioned about $1 / 4$ inch below the glass/cold cap interface while for the CETL tests shown in Table 6, the bubbler discharge was positioned at the glass/cold cap interface. With Frit 320 a bubbler hole was maintained throughout each of the test periods both at ACTL and CETL. On occasion the feed covered the bubbler vent but within a short time period (1 to 2 minutes) the vent re-appeared. The bubbler air was readily vented to the vapor space and no adverse effects on cold cap stability, foam persistence, or entrainment were observed. An $8.8 \%$ melt rate increase was observed when the bubbler was used in the ACTL SMRF. At comparable operating conditions the longer bubbler used in the CETL SMRF yielded a $12.0 \%$ melt rate increase, supporting the prediction of increased glass pumping with the longer draft tube. A significant increase (39\%) was obtained when the bubbler was used with the 52 wt $\%$ solids feed presumably because of improved distribution of the feed over the melt pool surface (i.e. increased cold cap coverage).

With Frit 200 however, a cold cap vent hole could not be maintained at this scale of testing and a thick crusty cold cap formed that grew with processing time. The cold cap thickness grew to several times the bubbler diameter, and the thickness of the cold cap was comparable to the length of the bubbler. Under these conditions the bubbler's capacity to burn a vent through the cold cap was overwhelmed, and the small bubbler was not sufficient. The cold cap trapped the 
bubbler air (no vent path available), which pressurized the melt pool and significantly increased the pour rate. As a result, no reliable melt rate determination could be made when the bubbler was used with Frit 200. Reducing the feed rate to the SMRF, raising the bubbler elevation, using a longer draft tube (CETL SMRF), or discharging in or on the cold cap may produce more favorable results and should be evaluated. A production scale unit would have a more massive glass flow stream, which should readily burn through the same thickness of cold cap.

Table 6. Bubbler Performance Summary with Frit 320

\begin{tabular}{|c|c|c|c|c|c|}
\hline Operating Condition & $\begin{array}{c}\text { SMRF } \\
\text { Location }\end{array}$ & $\begin{array}{c}\text { Feed Solids } \\
(\mathrm{wt} \%)\end{array}$ & $\begin{array}{c}\text { Bubbler } \\
\text { Flow Rate } \\
(\mathrm{scc} / \mathrm{min})\end{array}$ & $\begin{array}{c}\text { Plenum } \\
\text { Temperature } \\
\left({ }^{\circ} \mathrm{C}\right)\end{array}$ & $\begin{array}{c}\text { Melt Rate } \\
\text { Increase } \\
(\%)\end{array}$ \\
\hline Std Cond $40 \mathrm{wt} \%, 750^{\circ} \mathrm{C}$ & ACTL & 40 & 15 & 750 & 8.8 \\
\hline Low Plenum Temp & CETL & 41 & 5 & 650 & 14.3 \\
\hline High Feed Solids & CETL & 52 & 5 & 750 & 39.1 \\
\hline Std Cond $40 \mathrm{wt} \%, 750^{\circ} \mathrm{C}$ & CETL & 41 & 5 & 750 & 12.0 \\
\hline
\end{tabular}

Inspection of the power data in Table 7 shows that, in general, the impact of the bubbler was to increase the use of available melt pool power and decrease the demand for vapor space power. The additional energy from the melt pool was effectively used in increasing melt rate. For the high solids feed (52 wt \%), which had difficulty spreading out to cover the melter area, the bubbler improved feed distribution and the vapor space power increased, resulting in higher production rates. The lower plenum temperature run also shows a vapor space power increase with the bubbler. The over feeding condition experienced during the low plenum temperature tests may have contributed to this increased power demand. It appears, based on visual observation, that the foam layer in the cold cap is still a dominant factor limiting melt rate. The bubbler and Frit 320 are steps in the right direction, but eliminating the foam layer would appear to offer significant improvements in melt rate and melting behavior.

Table 7. SMRF Power Summary with Frit 320

\begin{tabular}{|c|c|c|c|c|c|c|}
\hline Run Date & $\begin{array}{c}\text { SMRF } \\
\text { Location }\end{array}$ & $\begin{array}{c}\text { Bubbler } \\
\text { Used }\end{array}$ & $\begin{array}{c}\text { Feed } \\
\text { Solids } \\
\text { Wt\% }\end{array}$ & $\begin{array}{c}\text { Avg. Plenum } \\
\text { Power } \\
\text { BTU }\end{array}$ & $\begin{array}{c}\text { Avg. Melt } \\
\text { Pool Power } \\
\text { BTU }\end{array}$ & $\begin{array}{c}\text { Glass Pour } \\
\text { Rate } \\
\text { (Grams/min) }\end{array}$ \\
\hline $7 / 30 / 02$ & ACTL & No & 40 & 124.9 & 53.8 & 13.7 \\
\hline $7 / 31 / 02$ & ACTL & Yes & 40 & 115.1 & 53.1 & 14.9 \\
\hline $8 / 30 / 02$ & CETL & No & 52 & 229.9 & 137.8 & 12.8 \\
\hline $9 / 3 / 02$ & CETL & Yes & 52 & 231.8 & 146.5 & 17.8 \\
\hline $9 / 4 / 02$ & CETL & Yes & 41 & 157.5 & 164.5 & 11.2 \\
\hline $9 / 4 / 02$ & CETL & No & 41 & 147.9 & 147.9 & 9.8 \\
\hline $9 / 5 / 02$ & CETL & Yes & 41 & 256.8 & 160.9 & 17.7 \\
\hline $9 / 27 / 02$ & CETL & No & 41 & 265.5 & 145.6 & 15.8 \\
\hline
\end{tabular}

Plenum temperature had a major effect on melt rate. A $100{ }^{\circ} \mathrm{C}$ drop in plenum temperature from $750{ }^{\circ} \mathrm{C}$ to $650{ }^{\circ} \mathrm{C}$ decreased melt rate nearly $40 \%$ from 15.8 grams $/ \mathrm{min}$ (9/27 test) to 9.8 grams $/ \mathrm{min}$. Adding a bubbler to the $650{ }^{\circ} \mathrm{C}$ plenum test improved melt rate to 11.2 grams $/ \mathrm{min}$, but it was still $29 \%$ lower than the rate obtained at $750{ }^{\circ} \mathrm{C}$. At the lower plenum temperature it was also much easier to get into an over feeding situation. These observations may well have an impact on the DWPF melter operation. It may be advantageous to control the DWPF melter 
slurry feed rate based on cold cap visual observation and melter pressure performance rather than solely on vapor space temperature.

\subsection{Recommendations}

1. The mini airlift bubbler offered a significant melt rate increase with Frit 320 without adversely affecting melting and cold cap behavior. Evaluation of the airlift bubbler in the DWPF melter should proceed expeditiously pending acceptable performance of the bubbler in the wear tests currently being conducted at the CETL.

2. Additional SMRF runs with Frit 200 should be made to evaluate the impact of the recommended processing changes on bubbler performance.

3. The foam layer on the melter surface is still a dominant factor limiting melt rate. Work on improving the melt rate should focus on understanding the source of the foam and eliminating the foam layer.

4. Low plenum temperature has a dramatic effect on melt rate and can lead to a severe overfeeding situation. Melter feed rate should not be set based on plenum temperature but rather, should be determined by visually controlling the cold cap coverage and appearance to avoid the overfeeding situation and resultant pressure spikes.

\subsection{References}

1. WSRC-TR-2002-00159 Rev. 0, "Steady and Transient Thermal Analysis of the DWPF Melter Operation", by H. N. Guerrero, October 2002.

2. WSRC-TR-2002-00196 Rev. 0, "DWPF Melter Air-Lift Bubbler: Development and Testing for Increasing Glass Melt Rates and Waste Dissolution", by H. N. Guerrero and. D. F. Bickford, October 2002.

3. WSRC-TR-2002-00421 Rev.0, "DWPF Melter Air-Lift Bubbler: Physical Testing with Glycerin”, by H. N. Guerrero and. D. F. Bickford, October 2002. 